Prepared in cooperation with the Buckman Direct Diversion Board, U.S. Forest Service, Albuquerque/Bernalillo County Water Utility Authority, U.S. Army Corps of Engineers, and Los Alamos County

\title{
Potential Postwildfire Debris-Flow Hazards- A Prewildfire Evaluation for the Jemez Mountains, North-Central New Mexico
}

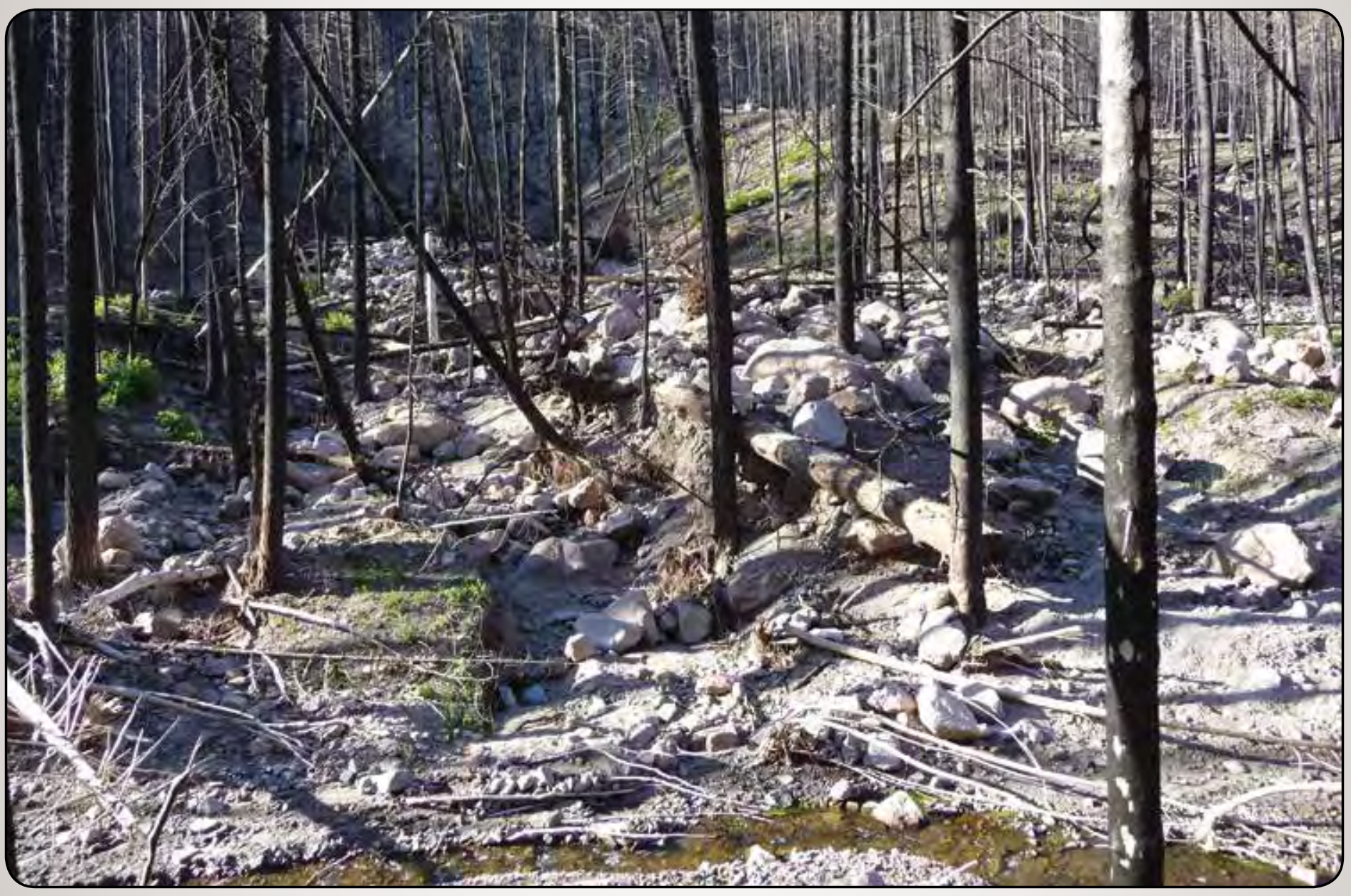

Scientific Investigations Report 2016-5101 
Cover: Photograph of debris flow in small tributary to Frijoles Canyon,

Bandelier National Monument, New Mexico. Photograph by Barbara Judy, National Park Service, May 2015. 


\section{Potential Postwildfire Debris-Flow Hazards- A Prewildfire Evaluation for the Jemez Mountains, North-Central New Mexico}

By Anne C. Tillery and Jessica R. Haas

Prepared in cooperation with the Buckman Direct Diversion Board, U.S. Forest Service, Albuquerque/Bernalillo County Water Utility Authority,

U.S. Army Corps of Engineers, and Los Alamos County

Scientific Investigations Report 2016-5101 


\title{
U.S. Department of the Interior SALLY JEWELL, Secretary
}

\section{U.S. Geological Survey Suzette M. Kimball, Director}

\author{
U.S. Geological Survey, Reston, Virginia: 2016
}

For more information on the USGS - the Federal source for science about the Earth, its natural and living resources, natural hazards, and the environment—visit http://www.usgs.gov or call 1-888-ASK-USGS.

For an overview of USGS information products, including maps, imagery, and publications, visit http://store.usgs.gov

Any use of trade, firm, or product names is for descriptive purposes only and does not imply endorsement by the U.S. Government.

Although this information product, for the most part, is in the public domain, it also may contain copyrighted materials as noted in the text. Permission to reproduce copyrighted items must be secured from the copyright owner.

Suggested citation:

Tillery, A.C., and Haas, J.R., 2016, Potential postwildfire debris-flow hazards-A prewildfire evaluation for the Jemez Mountains, north-central New Mexico: U.S. Geological Survey Scientific-Investigations Report 2016-5101, 27 p., http://dx.doi.org/10.3133/sir20165101.

ISSN 2328-0328 (online) 


\section{Contents}

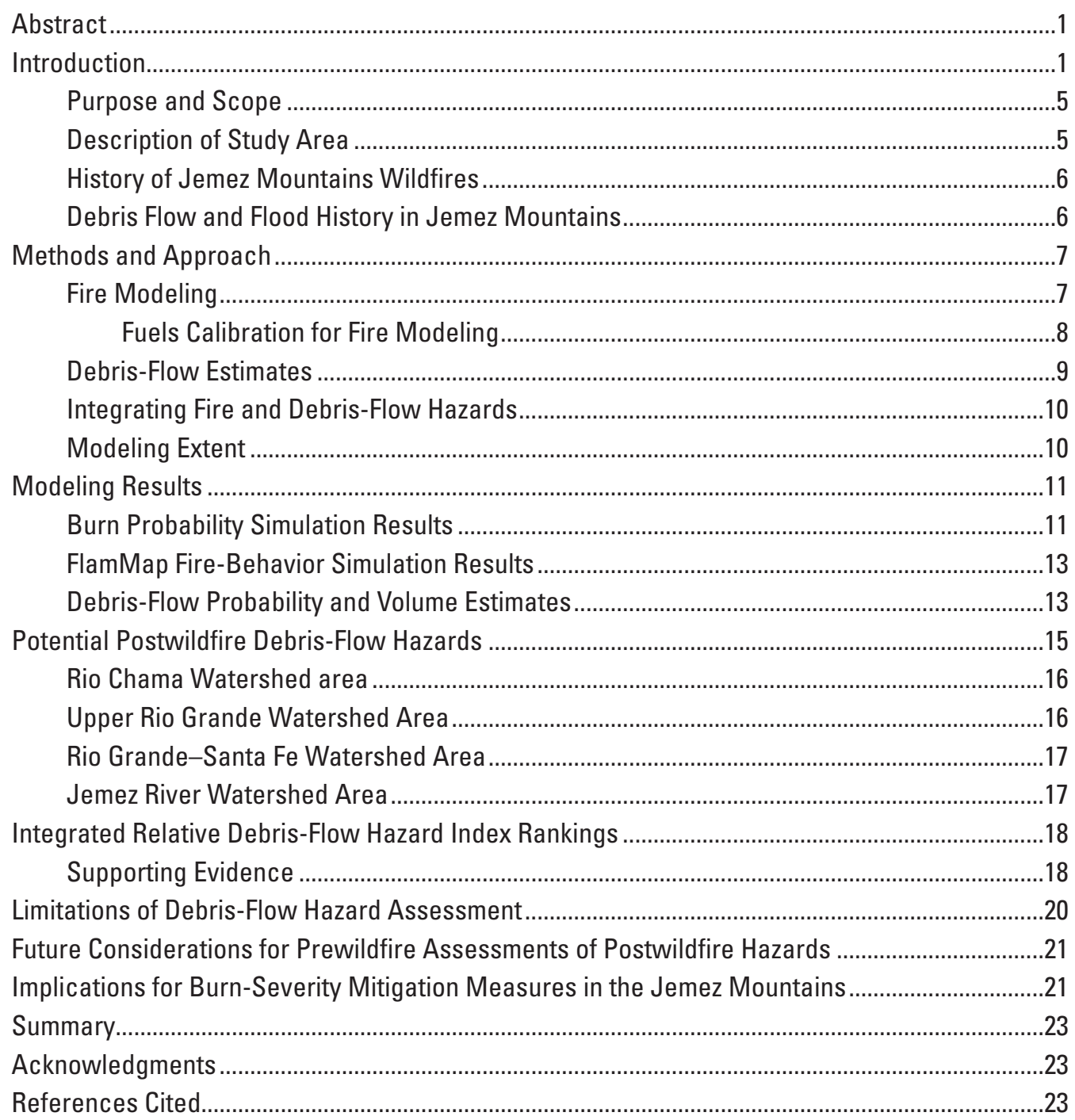




\section{Figures}

1. Maps showing location of study area and surrounding areas, and geographic features, Santa Fe National Forest Ranger Districts, and recent fire history, north-central New Mexico 3

2. Flow chart showing fire and debris-flow model interactions

3. Map showing results of burn-probability simulation, using U.S. Forest Service large-fire simulation system (FSim), Jemez Mountains and surrounding areas, north-central New MexicoEnvironmental Systems Resource Institute.

4. Map showing FlamMap-simulated burn severity, Jemez Mountains study area, north-central New Mexico.

5. Graph showing subbasin debris-flow probabilities with rainfall recurrence interval, Jemez Mountains, north-central New Mexico.

6. Scatterplot showing conditional debris-flow volume with debris-flow likelihood index for all modeled subbasins, Jemez Mountains, north-central New Mexico

7. Photographs showing debris-flow deposits associated with a tributary of Rito de los Frijoles, near the Upper Crossing in Bandelier National Monument with an Integrated Relative Debris-Flow Hazard Index Ranking in the top 20 percentile; in Santa Clara Canyon; and combined effects of upstream influx of debris in the main channel of Cochiti Canyon, Jemez Mountains, north-central New Mexico.

8. Graph showing basin debris-flow probabilities as a percentage of reduction in high and moderate burn severity, Jemez Mountains, north-central New Mexico

\section{Tables}

1. Major LANDFIRE fuel types in Jemez Mountains, north-central New Mexico

2. Rainfall recurrence intervals and basins with debris-flow probabilities greater than 80 and 90 percent, Jemez Mountains, north-central New Mexico

3. Debris-flow probability factors calculated for the 4,998 subbasins dataset for Jemez Mountains, north-central New Mexico.

4. Debris-flow probability scenarios, Jemez Mountains, north-central New Mexico .......22 


\section{Conversion Factors}

U.S. customary units to International System of Units

\begin{tabular}{|c|c|c|}
\hline Multiply & By & To obtain \\
\hline \multicolumn{3}{|c|}{ Length } \\
\hline inch (in.) & 2.54 & centimeter $(\mathrm{cm})$ \\
\hline inch (in.) & 25.4 & millimeter $(\mathrm{mm})$ \\
\hline foot (ft) & 0.3048 & meter $(\mathrm{m})$ \\
\hline mile (mi) & 1.609 & kilometer (km) \\
\hline \multicolumn{3}{|c|}{ Area } \\
\hline acre & 0.4047 & hectare (ha) \\
\hline acre & 0.4047 & square hectometer $\left(\mathrm{hm}^{2}\right)$ \\
\hline acre & 0.004047 & square kilometer $\left(\mathrm{km}^{2}\right)$ \\
\hline
\end{tabular}

International System of Units to U.S. customary units

\begin{tabular}{lcl}
\hline \multicolumn{1}{c}{ Multiply } & By & \multicolumn{1}{c}{ To obtain } \\
\hline centimeter $(\mathrm{cm})$ & Length & inch (in.) \\
millimeter $(\mathrm{mm})$ & 0.3937 & inch (in.) \\
meter $(\mathrm{m})$ & 0.03937 & foot $(\mathrm{ft})$ \\
kilometer $(\mathrm{km})$ & 3.281 & mile $(\mathrm{mi})$ \\
kilometer $(\mathrm{km})$ & 0.6214 & mile, nautical $(\mathrm{nmi})$ \\
\hline & 0.5400 & \\
\hline square meter $\left(\mathrm{m}^{2}\right)$ & Area & acre \\
square kilometer $\left(\mathrm{km}^{2}\right)$ & 0.0002471 & acre \\
square meter $\left(\mathrm{m}^{2}\right)$ & 247.1 & square kilometer $\left(\mathrm{ft}{ }^{2}\right)$ \\
square kilometer $\left(\mathrm{km}^{2}\right)$ & 10.76 & square mile $\left(\mathrm{mi}{ }^{2}\right)$ \\
\hline & 0.3861 & million gallons $(\mathrm{Mgal})$ \\
\hline cubic meter $\left(\mathrm{m}^{3}\right)$ & Volume & cubic foot $\left(\mathrm{ft}^{3}\right)$ \\
cubic meter $\left(\mathrm{m}^{3}\right)$ & 0.0002642 & cubic yard $\left(\mathrm{yd}^{3}\right)$ \\
cubic meter $\left(\mathrm{m}^{3}\right)$ & 35.31 & acre-foot $(\mathrm{acre}-\mathrm{ft})$ \\
cubic meter $\left(\mathrm{m}^{3}\right)$ & 1.308 & \\
\hline & 0.0008107 & mile per hour $(\mathrm{mi} / \mathrm{h})$ \\
\hline kilometer per hour $(\mathrm{km} / \mathrm{h})$ & Wind speed &
\end{tabular}

\section{Datums}

Vertical coordinate information is referenced to the North American Vertical Datum of 1988 (NAVD 88).

Horizontal coordinate information is referenced to the North American Datum of 1983 (NAD 83).

Elevation, as used in this report, refers to distance above the vertical datum. 


\title{
Abbreviations
}

\author{
$\mathrm{CBH} \quad$ Crown Base Height \\ $\mathrm{Cl} \quad$ Crown fire Index \\ ERC Energy Release Component \\ FSim USFS large-fire simulation system \\ LCP landscape file \\ NOAA National Oceanic and Atmospheric Administration \\ TI Torching index \\ USFS U.S. Forest Service \\ USGS U.S. Geological Survey
}




\title{
Potential Postwildfire Debris-Flow Hazards-A Prewildfire Evaluation for the Jemez Mountains, North-Central New Mexico
}

\author{
By Anne C. Tillery' and Jessica R. Haas ${ }^{2}$
}

\begin{abstract}
Wildfire can substantially increase the probability of debris flows, a potentially hazardous and destructive form of mass wasting, in landscapes that have otherwise been stable throughout recent history. Although the exact location, extent, and severity of wildfire or subsequent rainfall intensity and duration cannot be known, probabilities of fire and debris-flow occurrence for given locations can be estimated with geospatial analysis and modeling. The purpose of this report is to provide information on which watersheds might constitute the most serious potential debris-flow hazards in the event of a large-scale wildfire and subsequent rainfall in the Jemez Mountains. Potential probabilities and estimated volumes of postwildfire debris flows in both the unburned and previously burned areas of the Jemez Mountains and surrounding areas were estimated using empirical debris-flow models developed by the U.S. Geological Survey in combination with fire behavior and burn probability models developed by the U.S.
\end{abstract}

Forest Service.

Of the 4,998 subbasins modeled for this study, computed debris-flow probabilities in 671 subbasins were greater than 80 percent in response to the 100 -year recurrence interval, 30 -minute duration rainfall event. These subbasins ranged in size from 0.01 to 6.57 square kilometers $\left(\mathrm{km}^{2}\right)$, with an average area of $0.29 \mathrm{~km}^{2}$, and were mostly steep, upstream tributaries to larger channels in the area. Modeled debris-flow volumes in 465 subbasins were greater than 10,000 cubic meters $\left(\mathrm{m}^{3}\right)$, and 14 of those subbasins had modeled debris-flow volumes greater than $100,000 \mathrm{~m}^{3}$.

The rankings of integrated relative debris-flow hazard indexes for each subbasin were generated by multiplying the individual subbasin values for debris-flow volume, debris-flow probability, and average burn probability. The subbasins with integrated hazard index values in the top 2 percent typically are large, upland tributaries to canyons and channels primarily in the Upper Rio Grande and Rio Grande-Santa Fe watershed areas. No subbasins in this group have basin areas less than $1.0 \mathrm{~km}^{2}$. Many of these areas already had significant mass-wasting episodes following the Las Conchas Fire in 2011. Other subbasins with integrated hazard index values in the top 2 percent are scattered throughout the Jemez River watershed area, including some subbasins in the interior of the Valles Caldera. Only a few subbasins in the top integrated hazard index group are in the Rio Chama watershed area.

This prewildfire assessment approach is valuable to resource managers because the analysis of the debris-flow threat is made before a wildfire occurs, which facilitates prewildfire management, planning, and mitigation. In north-central New Mexico, widespread watershed restoration efforts are being done to safeguard vital watersheds against the threat of catastrophic wildfire. This study was designed to help select ideal locations for the restoration efforts that could have the best return on investment.

\section{Introduction}

Wildfire is a natural process in forest ecosystems and occurs with varying frequencies and severities depending on landscape characteristics, climatic conditions, and the historical fire regime. Although attention often is focused on the potential damages from wildfire in the wildland-urban interface, wildfire also presents a threat to critical infrastructure including flood-water conveyances and water conveyances critical to municipal water supplies. Further, burned landscapes are at risk of damage from postwildfire erosion, such as that caused by debris flows and flash floods, which can be the most catastrophic of the postwildfire threats to an area.

${ }^{1}$ U.S. Geological Survey.

${ }^{2}$ U.S. Forest Service. 
Debris flows are high-density slurries of water, rock fragments, soil, woody debris, and mud that can have enormous destructive power, particularly when they are fast moving. Debris flows are a common geomorphic process in response to intense rainfall in some unburned watersheds that have steep slopes, ample erodible materials, and minimal infiltration (Coe and others, 2008). Wildfire can drastically increase the probability of debris flows in landscapes that otherwise have been historically stable. A primary watershed effect of wildfire is rapid and substantial decrease in infiltration because of widespread removal of vegetation and development of hydrophobic soils (Cannon and Gartner, 2005). Although there is no way to know the location, extent, and severity of wildfire, or the subsequent rainfall intensity and duration before they happen, probabilities of fire and debris-flow occurrence for different locations can be estimated with geospatial analysis and modeling. These models can be useful planning tools to help better understand and mitigate the hazards of potential postwildfire debris flows.

Debris flows have been documented after many fires in the Western United States (Cannon, Bigio, and Mine, 2001; Cannon, Kirkham, and Parise, 2001; Cannon and others, 2010; DeGraff and others, 2011; Kean and others, 2011). Additionally, debris flows following wildfire can be generated in response to low recurrence-interval/high-intensity rainfall. Recently burned landscapes may be at risk of such postwildfire hydrologic hazards for several years following the fire (Cannon and Gartner, 2005). The U.S. Geological Survey (USGS) has developed a model (Cannon and others, 2010) to estimate postwildfire debris-flow probability and volume. This information can be used to determine watersheds of concern or areas most at risk for loss of life and property.

Another key spatial variable for hazard assessment and prioritization efforts is wildfire likelihood (Scott and others, 2013), typically measured as annual burn probability. Numerous studies have linked wildfire occurrence and extent to increasing spring and summer temperatures (Swetnam and Betancourt, 1990; Balling and others, 1992; Pierce and others, 2004; Westerling and others, 2006). The warmest and driest 2 -year period since record-keeping began in New Mexico in the late 1800s was during 2011-12 (Charles H. Jones, National Weather Service, written commun., 2014), and the wildfire seasons during those years included two of the largest fires in the State's history. Following several years of drought, during 2015 (January-August), statewide precipitation was 138 percent of normal or the third wettest calendar year on record (New Mexico Governor's Drought Task Force, 2015), which contributed to a buildup of continuous fuels (that is, fuel coverage that is spatially continuous and not interrupted by bare soil or rock). The most extensive fire activity in ponderosa pine forests, which are common in the study area, occurred in dry years following within 1-3 years of wet conditions (Allen, 2001). This pattern suggests the importance of fuel production during wet years and subsequent drought conditions, which enable fuels to burn widely (Swetnam and Baisan, 1996). Although drought conditions were reduced during 2015 because of above-average precipitation, the threat of future wildfires persists and could be exacerbated by the buildup of fuels during the recent period of above-average precipitation - hence, the need for prewildfire assessment and wildfire mitigation efforts.

Localized variation in the probability of burning is affected by factors such as topography and fuel, or vegetation characteristics, as well as fire-related weather patterns and ignition patterns. Spatial information on wildfire probability makes it possible to distinguish between basins and subbasins with potentially different likelihoods of wildfire occurrence, which can be an important distinction for efficient prioritization of wildfire mitigation efforts. Information on wildfire probability, therefore, is critical for assessing prewildfire risks. Combining debris-flow models with models for fire behavior and burn probability developed by the U.S. Forest Service (USFS) (Finney, 2006; Finney and others, 2011) allows for characterization of potential threats of postwildfire debris flows in watersheds with no wildfires in recent years.

A prewildfire evaluation to determine potential for postwildfire debris flows in the Jemez Mountains in north-central New Mexico (fig. 1) was started in 2014 by the USGS in cooperation with the Buckman Direct Diversion Board, USFS, the Albuquerque/Bernalillo County Water Utility Authority, the U.S. Army Corps of Engineers, and Los Alamos County as a part of the Rio Grande Water Fund. The USFS provided support for this effort, primarily through fire-simulation modeling.

In northern New Mexico, widespread restoration efforts are occurring to safeguard vital watersheds against the threat of catastrophic wildfire. This study was designed to help select ideal locations for the restoration efforts with potential for the best return on investment by local land management agencies. The Rio Grande Water Fund is an innovative project that engages private and public partners in protecting vital watersheds in northern New Mexico with a primary goal to generate sustainable funding for a 10-30-year program of large-scale forest and watershed restoration treatments (The Nature Conservancy, 2014). These restoration treatments could include thinning overgrown forests, restoring streams, and rehabilitating areas characterized by flooding and other damaging effects after wildfires. This study was designed to provide information on which subbasins might pose the most serious, potential debris-flow hazards in the event of a large-scale wildfire and subsequent rainfall in the Jemez Mountains and surrounding areas. 


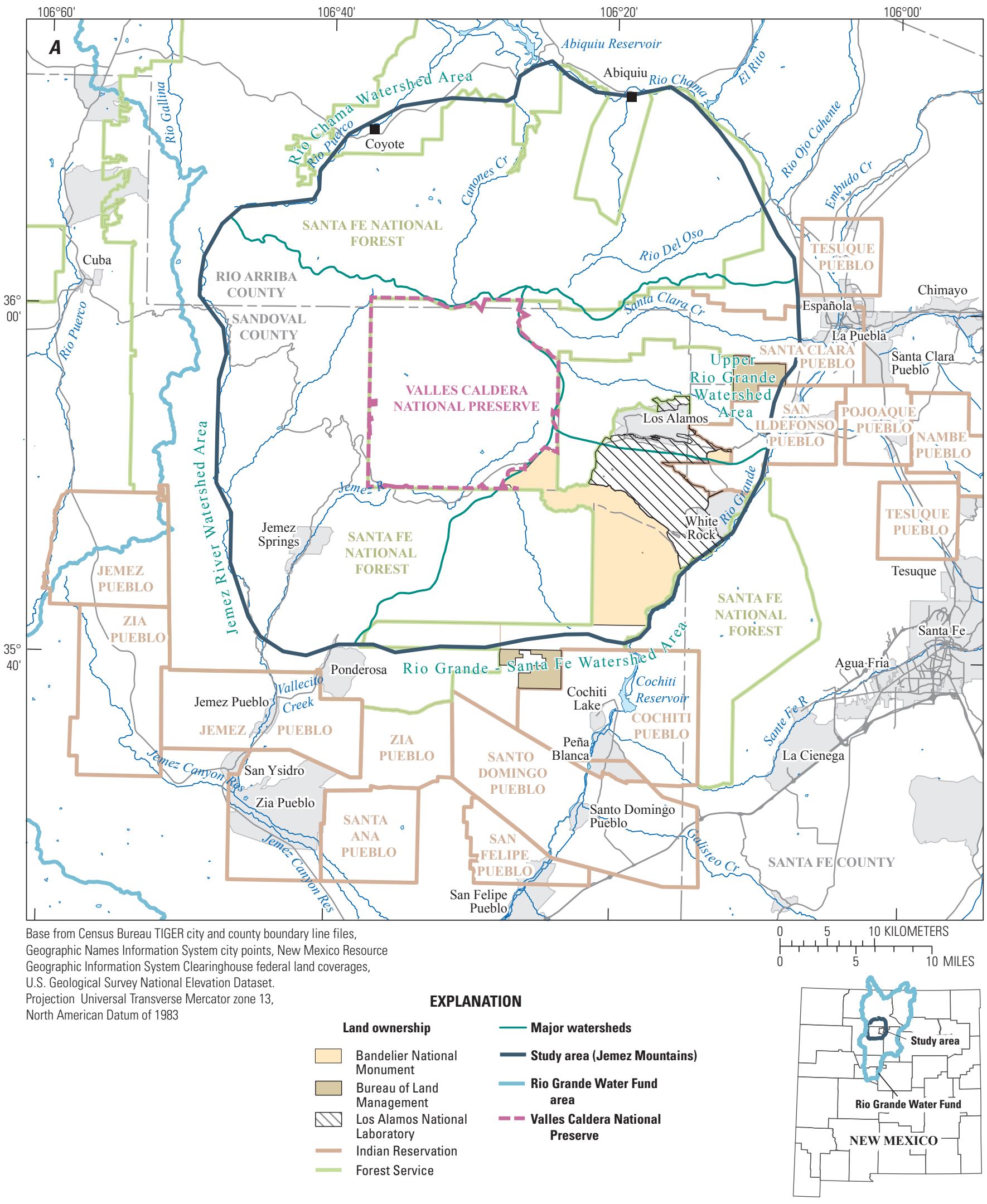

Figure 1. Location of $(A)$ study area and surrounding areas, and $(B)$ geographic features, Santa Fe National Forest Ranger Districts, and recent fire history, north-central New Mexico. 


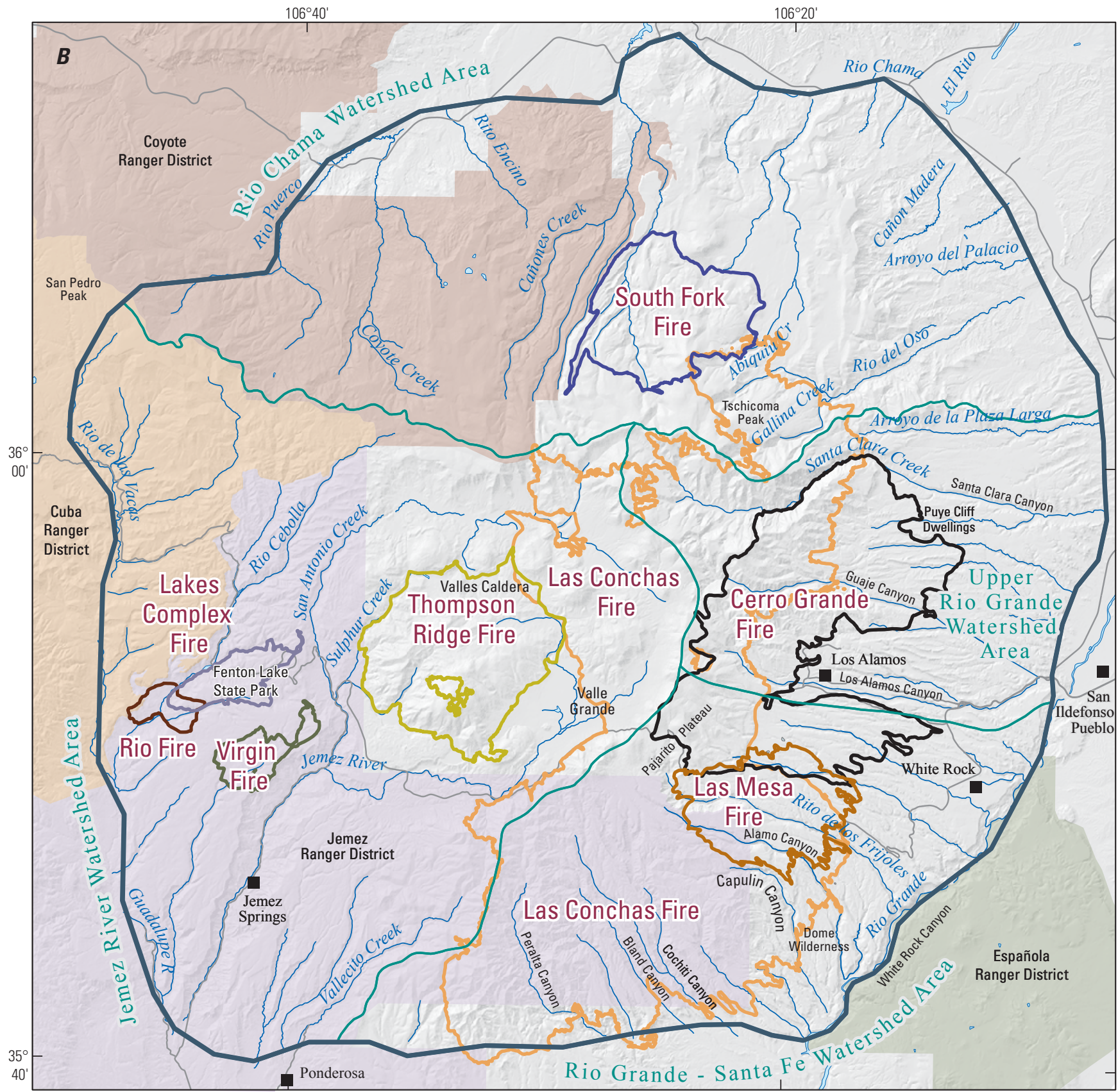

Base from Census Bureau TIGER city and county boundary line files, Geographic Names Information System city points, New Mexico Resource Geographic Information System Clearinghouse federal land coverages, U.S. Geological Survey National Elevation Dataset. Projection Universal Transverse Mercator zone 13, North American Datum of 1983

$$
\left.\right|_{0} ^{0}+\left.\left.\left.\right|_{1}||_{1}\right|_{1} ^{5}||_{5}||_{1}^{10}\right|_{10} ^{10} \text { MILOMETERS }
$$
EXPLANATION
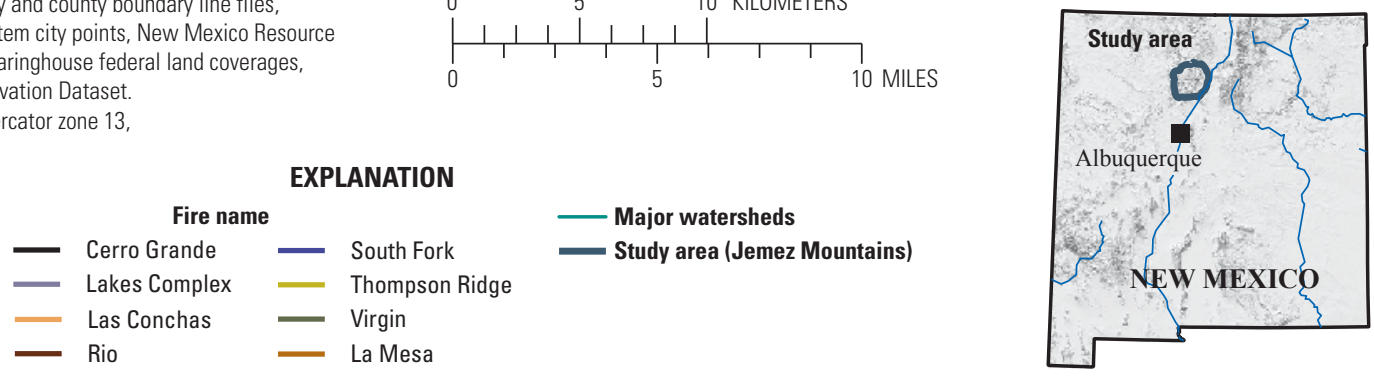

Figure 1.-Continued 


\section{Purpose and Scope}

This report presents estimates for the likelihood and potential magnitude of postwildfire debris flows for the unburned areas of the Jemez Mountains and surrounding areas (fig. 1A). The study area includes all mountainous regions in the Jemez Mountains and extends to the break in slope at the base of the mountains on all sides. The overarching modeling effort involved the coupling of multiple models for estimating spatial variation in burn probability, burn severity, and debris-flow hazard, a method which was initially applied in a study of the Sandia Mountains in central New Mexico and is described in detail in Tillery and others (2014, appendix 1). The USFS large-fire simulation system, referred to as FSim (Finney and others, 2011), was used to estimate burn probability, and the USFS fire-behavior model FlamMap (Finney, 2006) was used to estimate crown-fire activity and to infer burn severity likely to occur in the study area. The USGS postwildfire debris-flow models (Cannon and others, 2010) were used to estimate the probabilities of debris flows and volumes of material that could be transported through subbasins based on topography, soil characteristics, and simulated burn and precipitation intensities. The debris-flow modeling was completed for six design storms - 30-minute duration rainfall events with recurrence intervals of 2, 5, 10, 25, 50, and 100 years. These recurrence intervals are equivalent to annual exceedance probabilities of 50, 20,10, 4, 2, and 1 percent, respectively. An interactive map also has been developed to accompany this report to view results of the study (http://dx.doi.org/10.3133/ sir20165101).

This prewildfire assessment approach is valuable to resource managers because the analysis of the debris-flow threat is made before a wildfire occurs, which facilitates prewildfire management, planning, and mitigation.

Widespread watershed restoration efforts are being carried out to safeguard vital watersheds against the threat of catastrophic wildfire in northern New Mexico (The Nature Conservancy, 2014). A study to determine likely locations and sizes of postwildfire debris flows would facilitate efforts to mitigate the accumulation of prewildfire hazardous fuels, such as forest thinning, prescribed burning, and infrastructure stabilization by resource managers.

\section{Description of Study Area}

The study area $\left(3,100 \mathrm{~km}^{2}\right)$ includes all mountainous regions in the Jemez Mountains and extends to the break in slope at the base of the mountains on all sides (fig. 1B). The Jemez Mountains include forest and wilderness land as part of the Valles Caldera National Preserve, Bandelier National Monument, and to a much greater extent, the Santa Fe National Forest, including large parts of the Española, Jemez, Cuba, and Coyote Ranger Districts. Additionally, the Los Alamos National Laboratory and all or a part of several Pueblo Indian Tribal lands are located in the area encompassed by the Jemez Mountains. Multiple small towns and communities in the Jemez Mountains, including the City of Los Alamos and the Village of Jemez Springs, represent wildland-urban interface areas where homes, businesses, roads, and water-supply systems are adjacent to fuel-rich forests. The population in the Jemez Mountains area is about 25,000 (U.S. Census Bureau, 2010). Communities south of the Jemez Mountains that could be affected by upstream watersheds on the southern slopes of the Jemez Mountains include Jemez Pueblo, Ponderosa, Cochiti Pueblo, Peña Blanca, and the Town of Cochiti Lake. Cochiti Reservoir also could be affected. Communities east of the Jemez Mountains that could be affected by upstream watersheds on the eastern slopes of the Jemez Mountains include the City of Española, Santa Clara Pueblo, and San Ildefonso Pueblo. Additional small communities north of the Jemez Mountains that could be affected by upstream watersheds on the northern slopes of the Jemez Mountains include Abiquiu, Coyote, and others. Watersheds and communities of the Jemez Mountains and surrounding areas are vulnerable to several potential threats including wildfire and postwildfire hydrologic hazards.

The Jemez Mountains are the remains of a large volcano that underwent massive pyroclastic eruptions 1.4 and 1.1 million years ago and subsequently collapsed (fig. $1 B$; Burton, 1982). The central feature of the Jemez Mountains is the Valles Caldera, the collapsed volcanic crater, the rim of which is about $24 \mathrm{~km}$ in diameter. The volcanic caldera is surrounded by a circular ridge of mountains, the remnant of the pre-collapse volcanic pile. The mountains decrease in slope away from the caldera and eventually form canyon-dissected tuff plateaus that radiate outward from the center of the mountain range. The eastern slope between the Valles Caldera and White Rock Canyon of the Rio Grande is commonly referred to as the Pajarito Plateau (fig. 1B).

Most canyons radiating outward from the caldera contain ephemeral streams, or channels that flow intermittently, in some reaches. However, a few canyons contain perennial streams along their entire length. In addition to providing essential riparian habitat, these rare, high-desert, perennial streams serve other important purposes including irrigation, recreation, and sources of revenue for nearby communities. Some of the more prominent perennial streams in the area include Santa Clara Creek, which flows through Santa Clara Pueblo (fig. 1B); Rito de los Frijoles, which flows through Bandelier National Monument (figs. $1 A, 1 B$ ); Rio Cebolla, which flows through Fenton Lake State Park; and Rio del Oso in the Chama Watershed (fig. 1B). The Jemez River originates in the caldera and, in addition to the small perennial channels in the caldera, it also is fed by two larger, perennial tributaries on the western slopes of the Jemez Mountains: the Rio Guadalupe (Guadalupe River) and Vallecito Creek (fig. 1B). The Jemez River flows through several communities including Jemez Springs, Jemez Pueblo, San Ysidro, and Zia and Santa Ana Pueblos (figs. 1A), before joining the Rio Grande. 
Elevation in the study area ranges from $1,590 \mathrm{~m}$ $(5,216 \mathrm{ft})$ at the Rio Grande to $3,526 \mathrm{~m}(11,568 \mathrm{ft})$ at the summit of Tschicoma Peak (fig. $1 B$ ) (Touchan and others, 2011). Mean annual precipitation ranges from about $28 \mathrm{~cm}$ (11 in.) near the Rio Chama along the northern perimeter of the mountains to about $104 \mathrm{~cm}$ (41 in.) at San Pedro Peak just beyond the northwestern edge of the study area (Bonnin and others, 2004).

Vegetation communities in the Jemez Mountains vary with elevation and slope exposure. From the lowest elevations to the highest elevations, the vegetation communities are: 1,600-1,900 m, juniper (Juniperus monosperma) grasslands; 1,900-2,100 m, piñon pine (Pinus edulis) and juniper woodlands; 2,100-2,300 m, ponderosa pine (Pinus ponderosa) forests; 2,300-2,900 m, mixed conifer forests; and on the north slopes of the highest peaks, above 2,900 m, spruce (Picea sp.) and fir (Abies sp.) forests (Allen, 1989). Large breaks in the mixed conifer forest on upper south-facing slopes and large moist meadows in the caldera basin are populated with high-elevation grasslands.

\section{History of Jemez Mountains Wildfires}

Tree-ring reconstruction of fire history in the Jemez Mountains revealed that, prior to 1900 , forests in the Jemez Mountains were characterized by high-frequency, low-intensity surface-fire regimes occurring somewhat more frequently in the ponderosa pine forests (mean fire intervals ranging from 4.9 to 10.2 years) than in the mesic mixed-conifer forests (mean fire intervals ranging from 7 to 22 years) (Touchan and others, 1996). Major fire years were clearly associated with drought conditions, with the most extensive fire activity in ponderosa pine forests occurring in dry years that followed within 1-3 years of wet conditions, during which continuous fuels would have accumulated (Allen, 2001). After 1893, widespread fire occurrence generally ceased, coinciding with the onset of intensive livestock grazing across northern New Mexico (Touchan and others, 1996). Despite the grazing-induced decrease in widespread fire occurrence, about 5,200 historical fires were mapped in the Jemez Mountains for 1909-96, in a project using administrative records of local land-management agencies (D. Snyderman and C.D. Allen, U.S. Geological Survey, unpub. report, 1997).

Numerous large wildfires have occurred in the Jemez Mountains in recent years (fig. 1B). The 1977 La Mesa Fire burned 15,270 acres in and around Frijoles Canyon (Canyon in which Rito de los Frijoles flows, fig. 1B) on the southwestern flank of the Jemez Mountains in Bandelier National Monument and the adjacent Santa Fe National Forests (Veenhuis, 2002). The 1986 Dome Fire burned more than 16,500 acres in Capulin Canyon and the surrounding Dome Wilderness, also largely in Bandelier National Monument (Veenhuis, 2002). The 2000 Cerro Grande Fire was a particularly disastrous fire, partly because it was a controlled burn set by the National Park Service that rapidly turned into an uncontrolled fire, resulting in the evacuation of the Town of Los Alamos within 6 days of ignition. The nearby community of White Rock was evacuated the following day. The Cerro Grande Fire eventually burned 42,600 acres across the eastern face and flanks of the Jemez Mountains around and within Los Alamos, leaving 400 families without homes (Wilson and others, 2001). The Cerro Grande Fire Assistance Act (Public Law 106-246, 114 Stat. 584) to repair damages cost $\$ 661$ million, making it one of the most expensive fires in American history (Pyne, 2015). The South Fork Fire in 2010 burned 16,960 acres in a part of the northeastern flank of the Jemez Mountains (U.S. Geological Survey, 2015). The 2011 Las Conchas Fire burned an area greater than that of the Cerro Grande fire during the first 14 hours of ignition at a rate of about an acre per second (Bandelier National Monument, 2012). The fire eventually burned more than 156,000 acres across most of the southeastern flank and parts of the eastern and northeastern flanks of the Jemez Mountains, re-burning areas previously burned by the Cerro Grande Fire 11 years earlier. The Las Conchas Fire was the largest fire in New Mexico history, although it was surpassed the following year by the Whitewater-Baldy Complex Fire. The latest fire of substantial size in the Jemez Mountains area was the Thompson Ridge Fire in 2013, which burned 23,903 acres largely in the caldera (U.S. Geological Survey, 2015).

In the past century, forests such as those in the Jemez Mountains have sustained changes in stand structure including the formation of dog-hair thickets, decreased understory cover, and increased fuel loading (Covington and Moore, 1994) due partly to natural factors such as good seed crop years and anthropogenic factors such as grazing and fire suppression. Changes such as these have increased the probability of high-intensity fires.

\section{Debris Flow and Flood History in Jemez Mountains}

The Las Conchas Fire was quickly followed by record-breaking flooding in Cochiti, Santa Clara, and Frijoles (Rito de los Frijoles) Canyons (fig. $1 B$ ), damaging pueblo lands and recreation areas, and destroying a local apple farm. Floods in Santa Clara Canyon since the 2011 Las Conchas Fire have resulted not only in roads being damaged and destroyed, but ponds along Santa Clara Creek being filled with sediment and therefore rendered useless, heavy road equipment being swept away by flooding, and several people being left stranded and requiring rescue (Indian Country Today Media Network staff, 2013; New Mexico Legislature, 2014). As has been seen before in Santa Clara Canyon, debris flows in Santa Clara, Guaje, and Los Alamos Canyons have the potential to create hazardous conditions in locations downstream along the valley floors anywhere between where the debris flows occur 
and the Rio Grande, including communities such as Santa Clara Pueblo and Española. In the monsoon season following the Las Conchas Fire in 2011, debris from some of these channels traveled downstream far enough to affect the Cochiti Reservoir (Fleck, 2011; U.S. Army Corps of Engineers, 2012).

Following the 2001 Cerro Grande Fire, water-quality and sediment issues associated with the fire also were observed as far downstream as Cochiti Reservoir (Gallaher and Koch, 2004). This rapid transport and deposition of sediment could potentially affect agricultural lands, water quality, infrastructure, property, and human life on lands of Santa Clara Pueblo and in the City of Española.

Three large floods occurred in Frijoles Canyon at Bandelier National Monument during the first 2 years following the 2011 Las Conchas Fire (Barbara Judy, Bandelier National Monument, oral commun, 2013). With each of these floods, the flood peak was high enough in the headquarters area of the park to entirely flood a parking area along the creek near the visitor center by several feet. Flood waters also likely would have entered the visitor center if jersey barriers, sand bags, and other flood mitigation measures had not been in place at the time of the floods.

\section{Methods and Approach}

The hazard assessment presented in this report was created by combining the results of four wildfire hazardassessment models, a method which was initially applied in a study of the Sandia Mountains in central New Mexico and is described in detail in Tillery and others (2014, appendix 1). The four models used in this study include a large-fire simulation system model, a fire-behavior model, and two postwildfire debris-flow models. Postwildfire debris flows are the primary focus of this assessment. The postwildfire debris flows were modeled as probabilities and expected volumes in response to design storms according to the postwildfire debris-flow models developed by the USGS (Cannon and others, 2010).

\section{Fire Modeling}

Prewildfire assessment requires an estimation of where fires will occur or a burn probability for each location. The USFS large-fire simulation system, known as FSim (Finney and others, 2011), is a burn probability model that has been used in numerous wildfire exposure and risk assessments at various scales (Thompson and others, 2011; Ager and others, 2012) and to address effects on various resources (Scott and others, 2012; Haas and others, 2013; Thompson and others, 2013). Burn probabilities were estimated using the FSim burn probability model (Finney and others, 2011).
Postwildfire debris-flow assessments rely on burn severity information. Burn severity, as used in the Cannon and others (2010) debris-flow model, refers to the amount of canopy and surface vegetation consumed by the passing fire (Keeley, 2009). Moderate burn severity is defined as having at least some canopy loss, complete consumption of understory vegetation, and high consumption of dead surface fuels, whereas high burn severity refers to canopy trees being killed and the needles consumed, as well as the surface fuels being largely consumed (Turner and others, 1994; Ryan, 2002; Keeley, 2009).

At the time of this analysis (2014), fire-behavior models did not calculate burn severity; however, they did output fire intensity. Fire intensity is the amount of energy released when a fuel burns, and is measured in either kilowatts per meter or as flame height in meters (Alexander and Cruz, 2012). Through empirical modeling, intensity is used in generating fire-behavior outputs such as rate of spread and crown-fire initiation (Rothermel, 1972; Scott and Burgan, 2005; Alexander and Cruz, 2012). Intensity is highly correlated with severity, especially in forested landscapes, where high fire intensity will result in crown fire (Keeley, 2009). Crown fire is the movement of fire into and throughout the forest canopy, which results in relatively high levels of vegetation consumption and mortality and, therefore, is a useful proxy for moderate- and high-severity fire in forested landscapes.

The fire-behavior model FlamMap (Finney, 2006) incorporates spatial information on topography and fuel models, fuel moisture, and wind data to estimate a single set of fire-behavior outputs, including crown-fire potential. The crown-fire potential is generated spatially on a landscape file. Crown-fire potential was calculated using the Scott and Reinhart crown-fire method (Scott and Reinhart, 2001). Wind inputs were based on the most common combination of historically observed wind speed $(16 \mathrm{~km} / \mathrm{h})$ and direction (270 degrees) from the same weather inputs used in the FSim model. The crown-fire potential was generated for the 90th percentile Energy Release Component (ERC), a measure of fuel moisture. The 90th percentile ERC represents fuel dryness, often resulting in common large-fire growth and behavior. In forested landscapes, the resulting crown-fire potential was used as a surrogate for moderate- to high-severity fire.

In non-forested landscapes, such as shrub or grasslands, the surface-fuel model is a better indicator of moderate- to high-severity fire than crown-fire potential, since these landscapes do not possess a canopy. In grasslands, even a high-intensity fire typically results in low burn severity because of the rapid regeneration of grasses after a fire (Johansen and others, 2001). Therefore, areas mapped as a grassland surface-fuel model were not considered prone to moderate- and high-severity fire. In shrublands, high-intensity fires are highly correlated with moderate- and high-severity 
fire (Pyne and others, 1996; Keeley and others, 2008).

High-intensity shrub fuel models can be used as a surrogate for moderate- and high-severity fire potential in these communities. The shrub surface-fuel models SH5 and SH7, from $40 \mathrm{Scott}$ and Burgan fire-behavior fuel models (Scott and Burgan, 2005), have potential for high-intensity fire behavior. These fuel models were used to identify the areas with potential for moderate- and high-severity fire in shrublands.

Total moderate- and high-severity fire potential for the study area was calculated as the sum of the predicted crown-fire activity areas and the high-intensity shrub fuel areas. The resulting output was calibrated to observed burn severity using the Monitoring Trends in Burn Severity data (U.S. Geological Survey, 2013) for geographically relevant historical fires, based on the methods described in Tillery and others (2014, appendix 1).

\section{Fuels Calibration for Fire Modeling}

Spatial fuel and topography information needed to run both fire models was obtained from LANDFIRE (Ryan and Opperman, 2013; U.S. Geological Survey, 2013). LANDFIRE is an interagency mapping program responsible for producing and maintaining a suite of comprehensive and consistent geospatial layers representing topographic, vegetation, fuels, and fire conditions across the United States. The LANDFIRE topographic layers include slope, aspect, and elevation (Ryan and Opperman, 2013). The LANDFIRE fuels layers include data on canopy cover, canopy height, canopy base height, canopy bulk density, and the Scott and Burgan standard fire-behavior fuel models (Scott and Burgan, 2005). These inputs together comprise the landscape file (LCP) used in fire-behavior modeling. The LANDFIRE data that were used for this project were published in 2013 and include the updated conditions of areas burned through 2012. Specific methodology on the creation of the LANDFIRE topographic and fuels layers can be viewed with the data documentation (Ryan and Opperman, 2013).

The LANDFIRE National dataset was created to provide nationally consistent seamless data needed for large landscape fire-behavior modeling, in the form of the LCP. However, the LCP needs to be evaluated and potentially modified for use at the local to regional level (Stratton, 2009). A combination of fire specialists including fire-behavior modelers, fire-management officers, and fuels specialists form an effective team for evaluating and critiquing LCPs (Stratton, 2004; Bahro and others, 2007).

In May 2015, a group of fire ecologists, fire managers, fuels specialists and fire-behavior modelers met in Durango, Colorado, to evaluate the LANDFIRE National LCPs for the San Juan and Rio Grande National Forests and the surrounding Rio Grande Watershed. The results of this expert-judgment based meeting was a calibrated LCP that more accurately simulates local- to regional-level fire behavior than the LANDFIRE National product. The primary fire-behavior outputs to which the group calibrated the model inputs are flame length, rate of spread, torching index (TI, the wind-speed at which a surface fire begins to torch trees), and crown fire index $(\mathrm{CI}$, the wind-speed at which a surface fire transitions into a crown fire). These indexes are familiar to persons who have completed the necessary wildland fire-fighting training for use as a firefighter type-2, the most basic wildland firefighter position, as outlined in the PMS 310-1 Wildland Fire Qualification System Guide (National Wildfire Coordinating Group, 2015). These metrics are easily observed in the field, making them useful for expert judgment calibration.

Following the guidelines provided in Stratton (2009), two changes were made to the LCP. First, the surface-fuel model was changed within the Spruce-Fir, Mixed Conifer, and Aspen existing vegetation types. These existing vegetation types (EVT - LANDFIRE 2013) are mapped by LANDFIRE as fuel model Timber/Understory 5 (TU5). The calibration group agreed that this fuel model produces flame lengths and rates of spread that are unrealistic and too high for these vegetation types in this area. Therefore, a more suitable fuel model was selected for this vegetation type, Timber/Litter 3 (TL3), which produces moderate rates of spread and flame lengths. Second, the crown-fire initiation parameter was calibrated, through the TI and CI. The crown base height $(\mathrm{CBH}$, the average height from the ground to the canopy bottom of a forest stand, measured in meters) and canopy bulk density are the primary inputs that determine the crown-fire behavior. In order to obtain a realistic TI and CI, CBHs for Spruce/Fire fuels were adjusted to $0.4 \mathrm{~m}$ at $20-49$ percent canopy cover and $0.3 \mathrm{~m}$ at 50-100 percent canopy cover; CBHs for mixed conifer and aspen were adjusted to $0.4 \mathrm{~m}$ at 20-59 percent canopy cover and $0.3 \mathrm{~m}$ at $60-100$ percent canopy cover. The canopy bulk densities were appropriate, and no changes were made. A summary and description of the main fuel types present in the study area before and after calibration are shown in table 1 .

Table 1. Major LANDFIRE fuel types in Jemez Mountains, northcentral New Mexico.

[Fuel type: TU5, Timber/Understory 5; TL3, Timber/Litter 3]

\begin{tabular}{lcc}
\hline \multicolumn{1}{c}{ Fuel type } & $\begin{array}{c}\text { Before } \\
\text { calibration } \\
\text { (acres) }\end{array}$ & $\begin{array}{c}\text { After } \\
\text { calibration } \\
\text { (acres) }\end{array}$ \\
\hline Non burnable fuels & $1,046.4$ & $1,046.4$ \\
Grass fuel model & $7,152.2$ & $7,152.2$ \\
Grass/shrub fuel model & $12,405.6$ & $12,405.6$ \\
Shrub fuel model & $6,481.5$ & $6,481.5$ \\
Timber understory (includes TU5) & $24,772.1$ & $21,894.5$ \\
Timber litter (includes TL3) & $15,033.0$ & $17,910.8$ \\
\hline
\end{tabular}




\section{Debris-Flow Estimates}

Empirical models developed by Cannon and others (2010) were used to estimate the probabilities and volumes of debris flows along the drainage network and for selected drainage basins in response to a given rainfall event in the study area. The first model, for estimating debris-flow probability, was developed by Cannon and others (2010) using logistic multiple-regression analyses of data from 388 basins in 15 burned areas in the intermountain Western United States. Equation 1 was used to calculate debris-flow probability (Cannon and others, 2010):

$$
P=e^{x} /\left(1+e^{x}\right)
$$

where

$$
\begin{gathered}
P \quad \text { is the probability of debris-flow occurrence in } \\
\text { fractional form, and } \\
e^{x} \quad \text { is the exponential function where } e \text { represents } \\
\text { the mathematical constant } 2.718 \text {. }
\end{gathered}
$$

Equation 2 was used to calculate $x$ :

$$
\begin{aligned}
x=-0.7 & +0.03(\% S G 30)-1.6(R)+0.06(\% A B) \\
& +0.07(I)+0.2(\% C)-0.4(L L)
\end{aligned}
$$

where

$\% S G 30$ is the percentage of the drainage basin area with slope equal to or greater than 30 percent (using 10-m digital elevation models) (Gesch and others, 2002);

$R \quad$ is drainage basin ruggedness, the change in drainage basin elevation (in meters) divided by the square root of the drainage basin area (in square meters) (Melton, 1965);

$\% A B \quad$ is the percentage of drainage basin area burned at moderate and high severity;

$I \quad$ is average storm intensity (the total storm rainfall divided by the storm duration, in millimeters per hour) (Bonnin and others, 2006);

$\% C$ is the percentage of clay content of the soil (State Soil Geographic dataset [STATSGO]); Schwartz and Alexander, 1995); and

$L L \quad$ is the liquid limit of the soil (the percentage of soil moisture by weight at which soil begins to behave as a liquid) (STATSGO; Schwartz and Alexander, 1995).
Statistical analyses were used to identify the variables that most strongly influenced debris-flow volume and to develop the second model. Equation 3 was used to estimate

\begin{tabular}{|c|c|}
\hline$V$ & is the debris-flow volume (in cubic meters); \\
\hline $\ln$ & is the natural logarithm function; \\
\hline$G 30$ & $\begin{array}{l}\text { is the area of drainage basin with slopes equal } \\
\text { to or greater than } 30 \text { percent (in square }\end{array}$ \\
\hline & $\begin{array}{l}\text { kilometers) (using 10-m digital elevation } \\
\text { models) (Gesch and others, 2012); }\end{array}$ \\
\hline$A B$ & $\begin{array}{l}\text { is the drainage basin area burned at moderate } \\
\text { and high severity (in square kilometers); }\end{array}$ \\
\hline$T$ & is the total storm rainfall (in millimeters); and \\
\hline 0.3 & $\begin{array}{l}\text { is a bias correction factor that changes the } \\
\text { calculated estimate from a median to a } \\
\text { mean value (Helsel and Hirsch, 2002; } \\
\text { Cannon and others, 2010). }\end{array}$ \\
\hline
\end{tabular}
the volume of material that may pass through a drainagebasin outlet in response to a single rainfall event (Cannon and others, 2010):

$$
\begin{aligned}
& \ln (V)=7.2+0.6(\ln (S G 30)) \\
& +0.7(A B)^{0.5}+0.2(T)^{0.5}+0.3
\end{aligned}
$$

where

Values for debris-flow probability and volume were obtained along drainage networks using a modified version of the continuous parameterization technique (Verdin and Greenlee, 2003; Verdin and Worstell, 2008). With this technique, the values of model variables were obtained for every $10-\mathrm{m}$ pixel, and summarized for each stream segment (length of channel between tributary junctions). For each segment, the probability and volumes were estimated using equations 1,2 and 3. The technique used here allows for a synoptic view of conditions throughout the entire study area, which can be used to identify specific stream reaches that might pose a higher risk of debris flows; the technique also aids in sampling design and monitoring-site selection.

The base layer on which the continuous parameterization layers are built is the $1 / 2$ arc-second National Elevation Dataset (Gesch and others, 2002). This digital elevation model (DEM) was processed using standard DEM-conditioning tools in ArcGIS (Environmental Systems Resource Institute, 2011).

The debris-flow modeling was completed for six design storms - 30-minute duration rainfall events with recurrence intervals of $2,5,10,25,50$, and 100 years, respectively. Debris-flow modeling was completed by the USGS Landslide Hazard Group as a part the Emergency Assessment of Post-Fire Debris-Flow Hazards program (U.S. Geological Survey, 2016). 


\section{Integrating Fire and Debris-Flow Hazards}

Debris-flow hazards from a given subbasin also can be represented by an Integrated Relative Debris-Flow Hazard Index that is based on a combination of debris-flow probability, estimated volume of debris flow, and average burn probability for each basin. For example, the most hazardous subbasins would have the highest probabilities of fire occurrence (near or greater than 0.009 in this study) in some part of the subbasin, the highest probabilities of debris-flow occurrence (greater than 80 percent), and the largest estimated volumes of debris-flow material (greater than 100,000 m³). In contrast, less hazardous subbasins might have a combination of high probabilities of burning but only low probabilities (less than 50 percent) of moderate-volume (less than $100,000 \mathrm{~m}^{3}$ ) debris flows, or a combination of moderate probabilities of very-large-volume debris flows but only low probabilities of burning (less than 0.005 in this study).

To compute an integrated debris-flow hazard for each basin, it was necessary to generate a single burn probability value for each basin. To generate the individual basin burn probability values, the results of the simulation of FSim burn probability were averaged for each basin analyzed using the continuous parameterization method to create an average burn probability index (Tillery and others, 2014). Although the basin-average burn-probability index values do not actually quantify the likelihood of an entire basin burning in 1 year, they provide a measure of burn likeliness that is useful for prioritizing hazards by basins. This technique allowed for a synoptic view of conditions throughout the entire study area, which could be used to identify specific subbasins that might pose a higher risk of wildfire occurrence somewhere in the subbasin. By averaging over the entire basin, the within-basin spatial information provided by the burn probability values is lost; however, the basin-averaged values are not unreasonable compared to the spatially distributed values.

Computation of the integrated relative debris-flow hazard index for each subbasin was a two-step process. In the first step, the estimated debris-flow probability for each subbasin was multiplied by the average burn-probability index to produce a debris-flow likelihood index. In the second step, the debris-flow likelihood index for each subbasin was multiplied by the estimated debris-flow volume for that subbasin to produce an integrated relative debris-flow hazard index.
Additional technical details of the modeling methods and model interactions used in the study are available in Tillery and others (2014). The postwildfire debris-flow, FlamMap fire behavior, and FSim burn-probability modeling efforts are covered in detail in the appendix of that report.

The incorporation of the FSim burn-probability results provides important insight regarding where fires are most likely to occur in these unburned and recently burned landscapes (fire locations current as of 2014). Other efforts that have used FSim to focus on capturing spatial heterogeneity of fire likelihood and behavior have been limited in sophistication regarding modeling potential watershed effects (Scott and others, 2012; Thompson and others, 2013). The modeling efforts presented in this report represent a step forward by combining spatial wildfire modeling with debrisflow modeling to inform assessment and mitigation efforts. A version of the model interactions for this study is shown as a flow chart in figure 2 .

\section{Modeling Extent}

The extent needed to appropriately model burn probabilities is larger than those commonly used for debrisflow assessments, because of the nature of probabilistic fire-spread models. Fires that ignite in remote areas outside the study area, but spread into the study area, as well as those that ignite in the study area, had to be considered; therefore, the FSim project area includes the entire Rio Grande Water Fund boundary (fig. 1) with a $15-\mathrm{km}$ buffer. The FSim project area is $30,500 \mathrm{~km}^{2}$.

The debris-flow modeling extent was selected on the basis of three criteria: terrain, simulated burn severity, and precipitation patterns. The postwildfire, debris-flow models are designed for application in mountainous areas; therefore, the boundaries of the model were designed not to extend beyond the break in slope at the base of the Jemez Mountains on all sides. Additionally, National Oceanic and Atmospheric Administration (NOAA) Atlas 14 (Bonnin and others, 2004) isohyets were considered because they are indicative of areas with similar rainfall patterns; rainfall is a strong factor influencing debris-flow probability in the postwildfire, debris-flow model. 
FIRE MODEL INPUTS

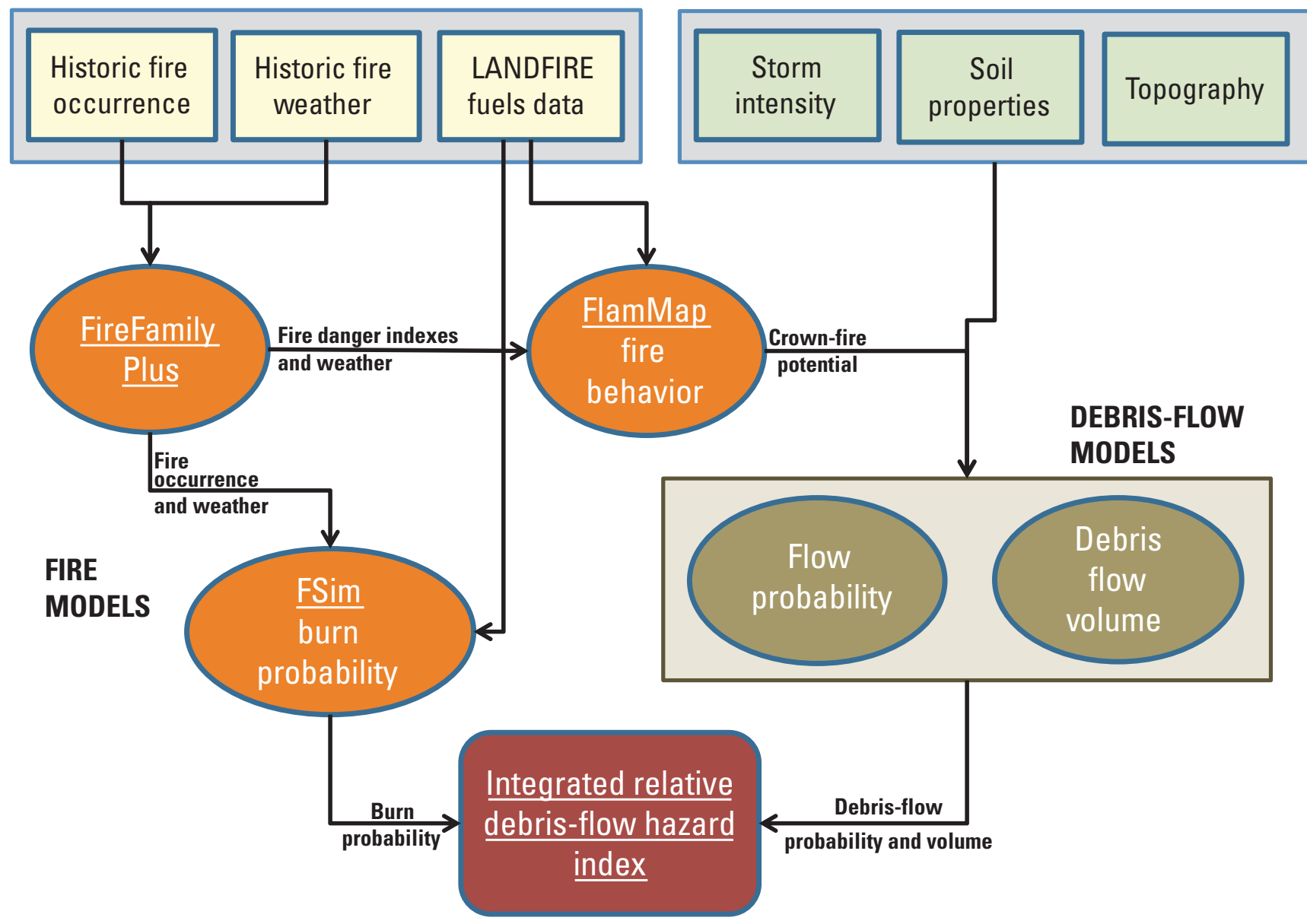

Figure 2. Fire and debris-flow model interactions.

\section{Modeling Results}

\section{Burn Probability Simulation Results}

The FSim annual burn probabilities vary across the entire landscape modeled from 0 to $1.45 \times 100$, with a mean burn probability of 0.003 (fig. 3). The FSim model outputs result in an average of 4.3 large fires (greater than 250 acres) per season, and an average of 28,500 acres burned per season. The burn probabilities are greatest in the valley bottoms and in mountainous areas, where fuel types with rapid rates of spread lead to large fire sizes. For the entire FSim project area, the burn probabilities are highest along the eastern edge of the modeling extent, outside of the study area. High burn-probability areas also occur throughout the Valles Caldera and the southwestern flank of the Jemez Mountains in addition to two areas north and outside of the study area.

Simulated burn probabilities do not appear to have a strong correlation to burn-scar areas. In some previously burned areas, such as the 2010 South Fork Fire, the burn probabilities were relatively low across the entire burn-scar area. In other burn-scar areas, such as the 2013 Thompson Ridge Fire burnscar area (fig. $1 B$ ), the burn probabilities remain high across much of the burn-scar area. The mid-elevation timber fuel areas have a lower burn probability relative to the adjacent shrubs and grass vegetation. Because of the difficulty of suppressing fires in remote timbered areas, fires that are established in areas with these characteristics tend to last a long time and, therefore, have the potential to burn large areas. 


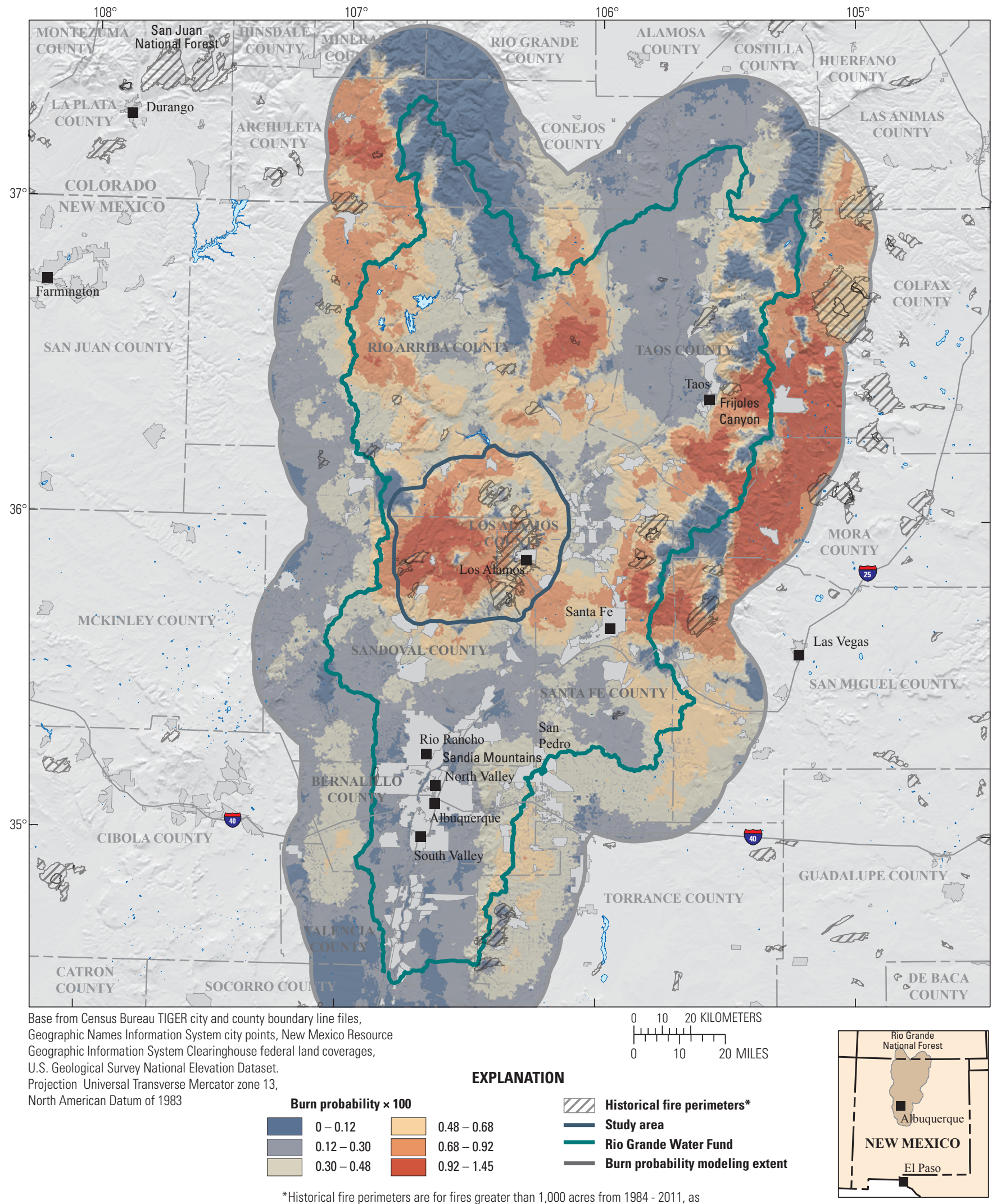

*Historical fire perimeters are for fires greater than 1,000 acres from 1984 - 2011, as mapped by the Monitoring Trends in Burn Severity project.

Figure 3. Results of burn-probability simulation, using U.S. Forest Service large-fire simulation system (FSim), Jemez Mountains and surrounding areas, north-central New Mexico. Burn probability is classified into six categories using natural breaks (Jenks) algorithm (de Smith and others, 2015) in ArcGIS software (Environmental Systems Resource Institute, 2011). 


\section{FlamMap Fire-Behavior Simulation Results}

FlamMap fire behavior is simulated either as surfacefire or crown-fire behavior. Within the study area, $1,661 \mathrm{~km}^{2}$ (53.7 percent of study area) were modeled as surface fire and $1,432 \mathrm{~km}^{2}$ (46.3 percent of study area) were modeled as crown fire (fig. 4). The results of the FlamMap simulation (fig. 4) show crown-fire activity only in locations where there are fuel models that can support crown fires, such as shrubs (27.4 percent of study area) and timber (57.7 percent of study area) (table 1).

The simulated surface-fire areas are more prevalent in the low elevations along the eastern edge of the study area, in the largest valley (Valle Grande) within the caldera, and in some of the past burn-scar areas. Although not always the case, some past burn-scar areas are obvious in the FlamMap simulation results appearing as rounded or oblong patches set apart from areas that otherwise are dominated by crownfire behavior. The South Fork Fire in the northern part of the study area is a good example of this. However, other recent burn-scar areas are dominated by simulated crownfire behavior, particularly areas burned by the 2011 Las Conchas Fire, possibly because of the type of shrub-dominated vegetation that is being reestablished in those areas. Landscape scars created by total canopy destruction, such as scars that occurred in the Las Conchas burn-scar area, can persist as grasslands or shrublands for decades to centuries after the fire because the relatively heavy, wingless seeds of the ponderosa pine cannot disperse far from surviving, mature trees (Allen and others, 2002).

\section{Debris-Flow Probability and Volume Estimates}

Other than rainfall intensity, the factors of burn severity and terrain most influence the debris-flow model; therefore, the locations of the greatest debris-flow hazards in the study area correlate with the areas with steepest slopes and simulated fire behavior of passive or active crown fire. The major drainages in the study area were delineated into 4,998 subbasins, ranging in area from 0.01 to $6.5 \mathrm{~km}^{2}$ and averaging $0.51 \mathrm{~km}^{2}$. The modeled area of the 4,998 subbasins encompasses a total area of $2,570 \mathrm{~km}^{2}$ or 83 percent of the $3,100-\mathrm{km}^{2}$ study area. The maximum size of $6.5 \mathrm{~km}^{2}$ was used because that is the largest sized basin that is represented with reasonable confidence in the debris-flow database used to generate the model (Gartner and others, 2005).
Analysis of debris-flow probabilities for this study area were calculated in response to the 2-, 5-, 10-, 25-, 50 -, and 100-year recurrence interval, 30-minute duration rainfall events, as determined by the NOAA Atlas 14 maps of rainfall frequency (Bonnin and others, 2004). Across the study area, rainfall intensities for the 100-year, 30-minute rainfall range from 48.9 to $69.2 \mathrm{~mm}$. The rainfall is assumed to have occurred within the first 3 years following a fire. High debris-flow probabilities (greater than 80 percent) indicate the combined effects of drainage basins being nearly completely burned at high and moderate severities and having steep slopes.

The model simulation results for a 100 -year recurrence interval, 30-minute duration rainfall event are used for discussion purposes because these results indicate the best differentiation of potential debris-flow probabilities among the drainage basins and best highlight the drainage basins with the highest probability of debris-flow response. Simulated hazard values for all other storms decrease with decreasing rainfall intensity. Across the entire study area, the probabilities of debris flows in response to the 100 -year recurrence interval, 30-minute duration rainfall event range from less than 1 percent to greater than 98 percent, with an average of 16 percent. Simulated debris-flow probabilities were greater than 80 percent (or "high") in 671 subbasins (13.4 percent of all subbasins) in response to the 100 -year recurrence interval, 30-minute rainfall event (table 2). The subbasins with probabilities greater than 80 percent ranged in size from 0.01 to $6.57 \mathrm{~km}^{2}$, with an average area of $0.29 \mathrm{~km}^{2}$. This small average subbasin size with high probabilities of debris-flows is indicative of the steep slopes associated with the small, upland tributaries, and side channels of the main channels.

Table 2. Rainfall recurrence intervals and basins with debrisflow probabilities greater than 80 and 90 percent, Jemez Mountains, north-central New Mexico.

\begin{tabular}{|c|c|c|c|c|}
\hline \multirow{2}{*}{$\begin{array}{l}\text { Rainfall } \\
\text { recurrence } \\
\text { interval }\end{array}$} & \multicolumn{2}{|c|}{$\begin{array}{l}\text { Basins with debris-flow } \\
\text { probabilities greater than } \\
80 \text { percent }\end{array}$} & \multicolumn{2}{|c|}{$\begin{array}{c}\text { Basins with debris-flow } \\
\text { probabilities greater than } \\
90 \text { percent }\end{array}$} \\
\hline & $\begin{array}{l}\text { Number of } \\
\text { subbasins }\end{array}$ & $\begin{array}{l}\text { Percentage } \\
\text { of subbasins }\end{array}$ & $\begin{array}{l}\text { Number of } \\
\text { subbasins }\end{array}$ & $\begin{array}{l}\text { Percentage } \\
\text { of subbasins }\end{array}$ \\
\hline 2-year & 9 & 0.2 & 0 & 0.0 \\
\hline 5-year & 56 & 1.1 & 1 & 0.0 \\
\hline 10-year & 130 & 2.6 & 20 & 0.4 \\
\hline 25-year & 276 & 5.5 & 83 & 1.7 \\
\hline 50-year & 429 & 8.6 & 166 & 3.3 \\
\hline 100-year & 671 & 13.4 & 289 & 5.8 \\
\hline
\end{tabular}




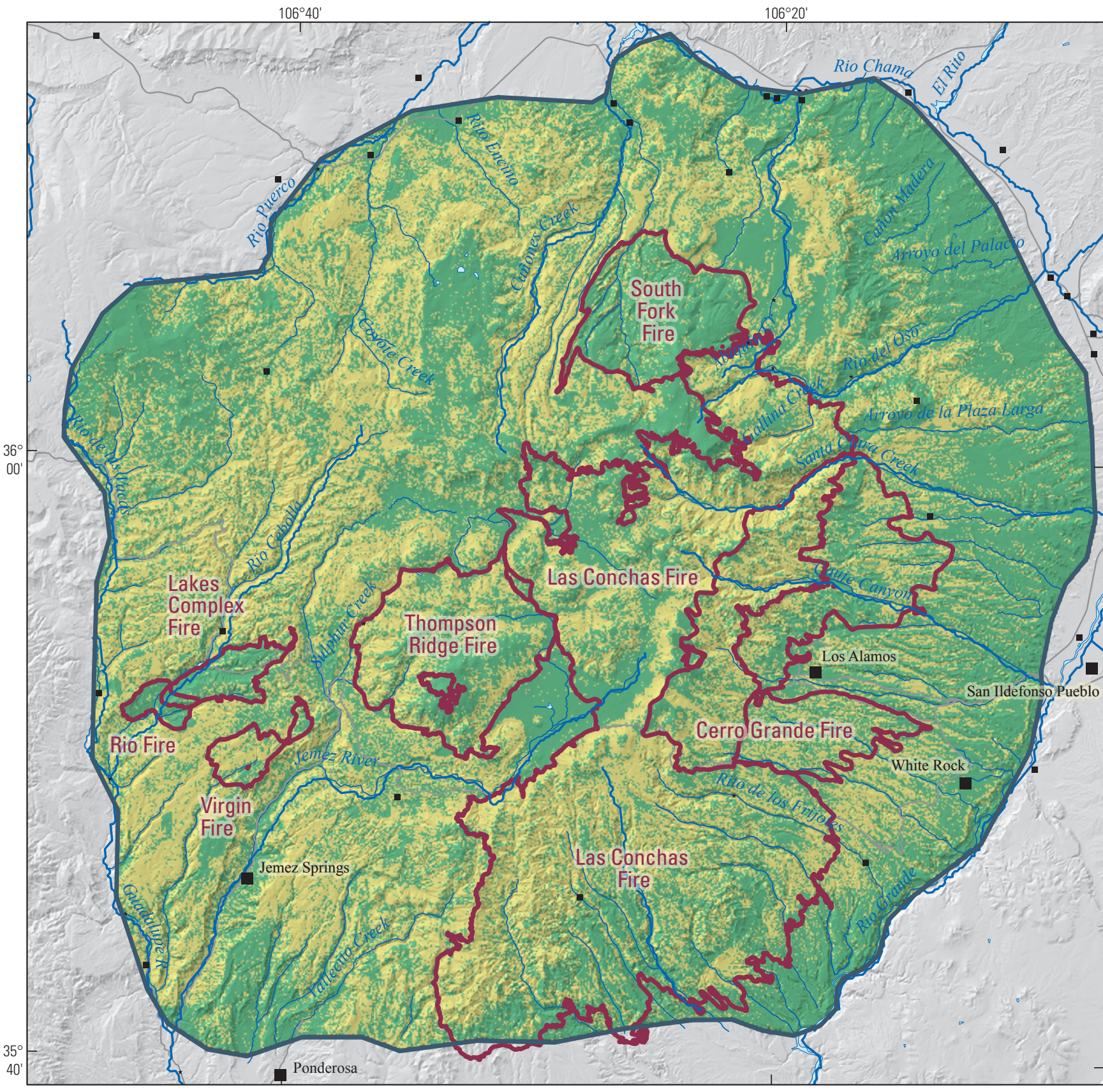

Base from Census Bureau TIGER city and county boundary line files, Geographic Names Information System city points, New Mexico Resource Geographic Information System Clearinghouse federal land coverages, U.S. Geological Survey National Elevation Dataset. Projection Universal Transverse Mercator zone 13, North American Datum of 1983

\section{EXPLANATION}

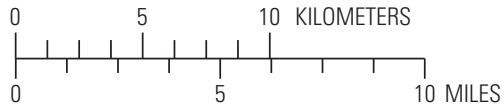

Simulated burn severity

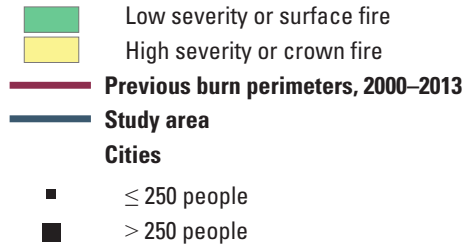

Figure 4. FlamMap-simulated burn severity, Jemez Mountains study area, north-central New Mexico 
Probability of debris flow is strongly related to rainfall intensity. Subbasin debris-flow probabilities greater than 80 percent increase consistently across the study areas as the storm recurrence interval increases. When comparing results of debris-flow probabilities between rainfall events with the 25-year and 100-year recurrence intervals, subbasin debris-flow probabilities greater than 90 percent increase 249 percent across the study area. The number of subbasins with debris-flow probabilities greater than 80 percent is 144 percent higher when looking at the 100-year recurrence interval rainfall event as compared to the rainfall with a 25-year recurrence interval. A breakdown of the debris-flow probabilities greater than 80 percent by subbasin in response to all rainfall periods modeled is summarized in table 2 and figure 5.

Estimated debris-flow volumes in response to the 100-year recurrence interval, 30-minute duration rainfall event ranged from slightly more than $30 \mathrm{~m}^{3}$ to more than $180,000 \mathrm{~m}^{3}$ and averaged greater than $4,500 \mathrm{~m}^{3}$. Estimated volumes in 451 subbasins were greater than $10,000 \mathrm{~m}^{3}$. Estimated debrisflow volume is closely related to basin area, so subbasins with the largest areas also are the subbasins with the largest estimated debris-flow volumes.

\section{Potential Postwildfire Debris-Flow Hazards}

An interactive map has been developed using the results from this analysis and is available at http://dx.doi.org/10.3133/ sir20165101. The user can zoom in or out to areas of interest and select data overlays including basin and segment analysis of debris-flow probability, debris-flow volume, and integrated hazard. Drainages, watersheds, and base map data can be added to or removed from the map. The user can also select "no data overlay" to only view drainages, watersheds, or base map data. The ArcGIS ${ }^{\mathrm{TM}}$ shapefiles used in making this map can be downloaded at http://dx.doi.org/10.3133/sir20165101.

The 4,998 subbasins analyzed have been grouped together into four major watershed areas to facilitate ease of discussion. In clockwise order (from the north), the four major watershed areas are the Rio Chama, the Upper Rio Grande, the Rio Grande-Santa Fe, and the Jemez River (figs. 1A, $1 B$, and interactive map). Although six storms were modeled in this study, for the purpose of simplicity, the interactive map and discussion focus on the results of the simulation of the 100-year recurrence interval, 30-minute duration

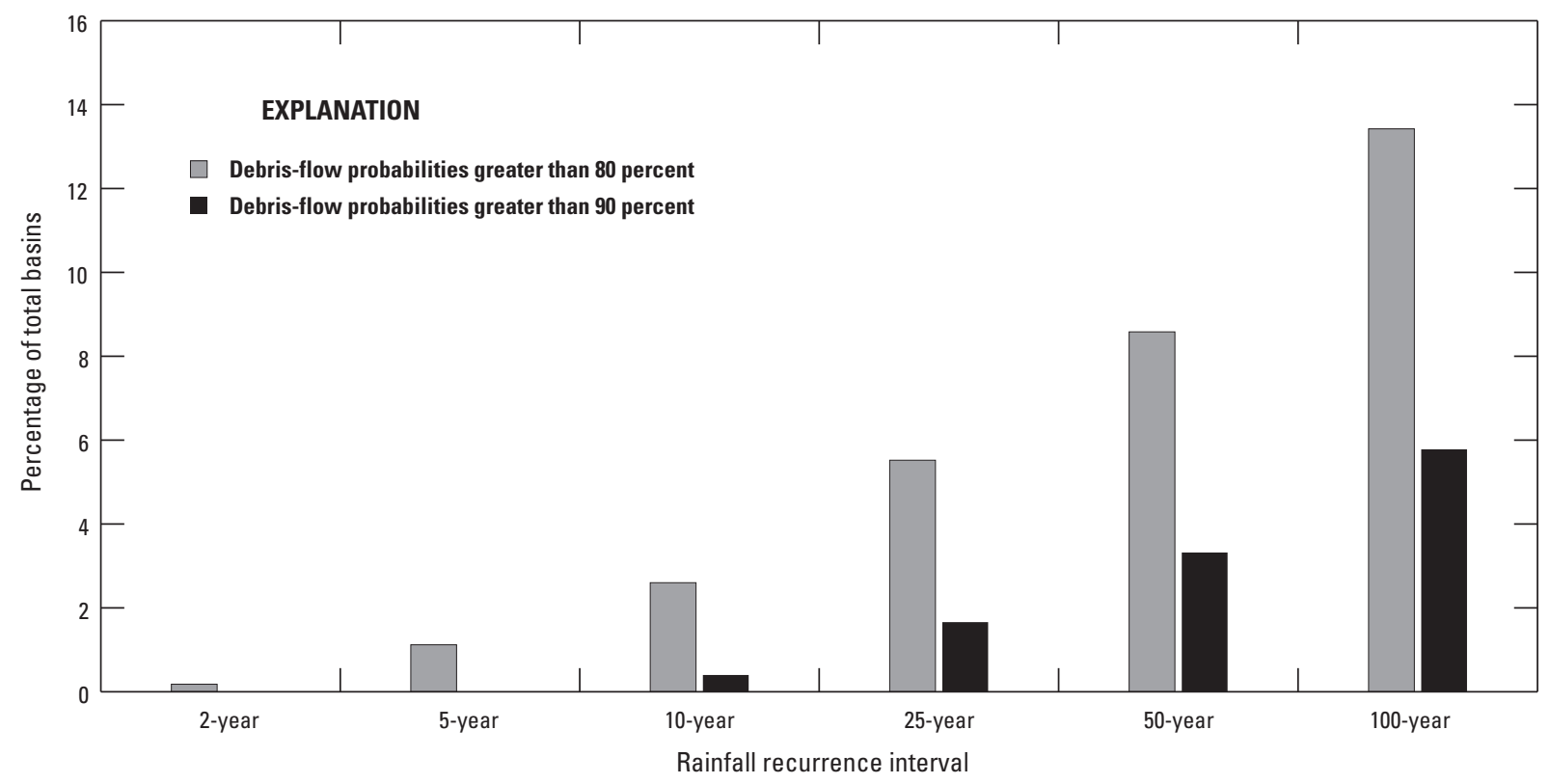

Figure 5. Subbasin debris-flow probabilities with rainfall recurrence interval, Jemez Mountains, northcentral New Mexico. 
rainfall event. For this study, debris-flow probabilities are classified into five categories of 20 percent each with "high" debris-flow probabilities being those greater than 80 percent. This simulation provides a sufficiently wide range of basin responses that makes it useful in prioritizing basin hazards and potential mitigation-measure locations. Stream reaches draining the delineated subbasins are shown on the interactive map as "drainages that can be affected by the combined effects of debris flows."

The maps produced in this study do not categorize those areas that can be affected as the debris travels downstream of the basin outlets (Cannon and others, 2010). The maps categorize only those areas from which debris will be removed. Debris flows can travel long distances downstream of their points of origin and can cause additional damage in the form of sediment erosion and aggradation at any point along the path that they travel. The combined effects of numerous small, side channels and steep slopes contributing debris to main channels by way of side-channel debris flows can lead to channel aggradation, obstruction of the flood path, and other problems in the main channels.

\section{Rio Chama Watershed area}

The Rio Chama watershed area (see figs. $1 A, 1 B$, and interactive map at $h t t p: / / d x . d o i . o r g / 10.3133 / \operatorname{sir} 20165101$ ) is the most northern watershed area of the study area. Most channels in this watershed area that drain to the north and east flow directly into Rio Chama or into Abiquiu Reservoir, a reservoir on the Rio Chama. A few channels in the western part of the watershed area flow to an upstream tributary of the Rio Chama called the Rio Puerco. The closely spaced, parallel stream channels in the center of the watershed area eventually converge into Cañones Creek (fig. 1B), a perennial channel that flows into Abiquiu Reservoir, as does Coyote Creek to the west of Cañones Creek. Most of the land in this area is managed by the Española and Coyote Ranger Districts of the Santa Fe National Forest. Many small communities in and around this watershed area typically are located near small streams or along the banks of the Rio Chama. A total of 1,358 subbasin areas are delineated in the Rio Chama watershed area totaling $798 \mathrm{~km}^{2}$ or 31.0 percent of the total basin area delineated in the study area. Outside the narrow incised canyons, which can have steep side slopes, the Rio Chama watershed area has relatively gentle topography compared to the other watershed areas. Burn severity in the Rio Chama watershed area is high in forested areas where fuel models support sustained crown fires.

The debris-flow probabilities in response to the modeled 100-year, 30-minute rainfall event in the Rio Chama watershed area (interactive map) range from less than 1 percent to greater than 98 percent and average about 30 percent (median of 19 percent). No subbasins in this watershed area have estimated debris-flow volumes greater than $100,000 \mathrm{~m}^{3}$. The estimated debris-flow volumes range from just more than $30 \mathrm{~m}^{3}$ to nearly $80,000 \mathrm{~m}^{3}$ and average about $4,100 \mathrm{~m}^{3}$ (median of 1,120 $\mathrm{m}^{3}$ ). The Rio Chama watershed area contains 138 subbasins that have debris-flow probabilities greater than 80 percent, mostly in the small tributaries to the westernmost Cañones Creek Tributary, in the upland areas of the eastwarddraining Rio del Oso, and in the upland tributaries of the northward-flowing Coyote Creek in the western part of the watershed area. Sediment and debris mobilization in the upper tributaries of Cañones and Coyote Creeks could lead to sediment issues downstream in Abiquiu Reservoir. The small communities in and downstream of this watershed area could be affected by the combined influences of small debris flows occurring in the upland parts of watersheds and sediment and debris being transported to downstream locations.

\section{Upper Rio Grande Watershed Area}

The Upper Rio Grande watershed area drains the plateau on the eastern flank of the Jemez Mountains, known locally as the Pajarito Plateau (fig. 1B). The Upper Rio Grande watershed area stretches from the Valles Caldera basin divide on the western edge eastward to the White Rock Canyon of the Rio Grande. The topography of this area is characterized by a sloping plateau that is heavily dissected by parallel, narrow, east-west trending canyons that flow toward the Rio Grande. A large part of this watershed area is managed by the USFS as part of the Santa Fe National Forest. The City of Los Alamos and nearby Los Alamos National Laboratory are in the Upper Rio Grande watershed area. The City of Española and Santa Clara Pueblo are downstream of channels draining the plateau including Santa Clara Creek, a perennial stream that has had significant flooding and sediment mobilization since the 2011 Las Conchas Fire (Indian Country Today Media Network staff, 2013; New Mexico Legislature, 2014). The Puye Cliff Dwellings, a National Historic Landmark, also are located in Santa Clara Canyon. There are 663 basin areas delineated in the Upper Rio Grande watershed area totaling $309 \mathrm{~km}^{2}$ or 12.0 percent of the total basin areas delineated in the study area. The simulated burn severity based on crown-fire activity (fig. 4) is high in patchy areas in the higher elevations and on the upper slopes of larger canyons in the area.

The debris-flow probabilities in response to the modeled 100-year, 30-minute rainfall event in the Upper Rio Grande watershed area (interactive map) range from less than 1 percent to greater than 98 percent and average about 38 percent (median of 28 percent). This watershed area has one of the highest concentrations of basins with high probabilities (greater than 80 percent) of debris flow in the study area. Nearly 20 percent of the subbasins in this watershed area, or 127 subbasins, have debris-flow probabilities greater than 80 percent, most of which are 
upstream tributaries of Santa Clara Creek, Guaje Canyon, and Los Alamos Canyon. Only 14 subbasins in the entire Jemez Mountains study area have estimated debris-flow volumes greater than $100,000 \mathrm{~m}^{3}$, and 4 of those are in this watershed area, including 2 upstream tributaries to Guaje Canyon and 1 to Los Alamos Canyon. The estimated debris-flow volumes in this area range from nearly $30 \mathrm{~m}^{3}$ to more than $150,000 \mathrm{~m}^{3}$ and average about $4,800 \mathrm{~m}^{3}$ (median of $1,070 \mathrm{~m}^{3}$ ).

\section{Rio Grande-Santa Fe Watershed Area}

The Rio Grande-Santa Fe watershed area drains the southeastern flank of the Jemez Mountains towards the Rio Grande (interactive map). As with other watershed areas on the flanks of the Jemez Mountains, the topography of the Rio Grande-Santa Fe watershed area is characterized by a sloping plateau that is heavily dissected by parallel, narrow canyons that flow southeast toward the Rio Grande. In the Rio Grande-Santa Fe watershed area, 899 delineated basin areas total $482 \mathrm{~km}^{2}$ or 18.7 percent of the total basin areas delineated in the study area. The protected cliff dwellings and ancestral Pueblo Indian ruins of Bandelier National Monument are completely encompassed by the Rio GrandeSanta Fe watershed area. Rito de los Frijoles, which runs through Frijoles Canyon in Bandelier National Monument, is one of few perennial streams in the area. The community of White Rock sits on the edge of White Rock Canyon in the eastern edge of this watershed area. Cochiti Pueblo and the Town of Cochiti Lake (fig. $1 A$ ) are located along the Rio Grande immediately downstream of the study area. Despite being burned by the Las Conchas Fire in 2011, much of this watershed area shows a high simulated burn intensity.

The debris-flow probabilities in response to the modeled 100-year, 30-minute rainfall event in the Rio Grande-Santa Fe watershed area (interactive map) range from less than 1 percent to greater than 96 percent and average around 32 percent (median of 22 percent). This watershed area has the second highest concentration of basins with high probabilities of debris flow in the study area. About 11 percent of the subbasins in this watershed area, or 104 total subbasins, have debris-flow probabilities greater than 80 percent, all of which are located in upstream tributaries to Peralta, Cochiti, and Bland Canyons (fig. $1 B$ ). Some small side tributaries to other canyons such as Frijoles Canyon in Bandelier National Monument also have modeled debris-flow probabilities greater than 80 percent. The estimated debris-flow volumes in this area range from about $30 \mathrm{~m}^{3}$ to more than $180,000 \mathrm{~m}^{3}$ and average around $6,100 \mathrm{~m}^{3}$ (median of $1,300 \mathrm{~m}^{3}$ ). Of the 14 subbasins in the entire Jemez Mountains study area that have estimated debris-flow volumes exceeding $100,000 \mathrm{~m}^{3}$, 10 are in Rio Grande-Santa Fe watershed area, including the highest estimated volume in the study area of more than $180,000 \mathrm{~m}^{3}$ in an upstream tributary to Cochiti Canyon. Debris flows in Bland, Cochiti, and Alamo Canyons (fig. 1B) may create hazardous conditions along the valley floors for miles downstream. In this case, the rapid transport and deposition of large volumes of sediment could potentially affect agricultural lands, water quality, infrastructure, property, and human life on lands of Cochiti Pueblo and in the Town of Cochiti Lake.

\section{Jemez River Watershed Area}

The Jemez River watershed area includes the interior of the Valles Caldera and most of the western flank of the Jemez Mountains as far west as the Rio de las Vacas, to the north, and the Rio Guadalupe, to the south, making it the largest of the four watershed areas (fig. $1 B$; interactive map). Most of this watershed area is managed by the USFS as a part of the Santa Fe National Forest including most of the Jemez Ranger District lands and a large part of the Cuba Ranger District lands. Management of the Valles Caldera recently (2015) has been transferred from the USFS to the National Park Service. The Jemez River is a perennial stream fed partly by numerous geothermal hot and warm springs, and provides recreational uses such as fishing, hiking, and camping in addition to publicly and privately available hot springs. The Jemez River runs through the community of Jemez Springs in the study area and through Jemez, Zia, and Santa Ana Pueblos along with the community of San Ysidro downstream of the study area (fig. 1A). This watershed area has 2,078 delineated subbasins. Basin areas delineated in the Jemez River watershed area total $982 \mathrm{~km}^{2}$ or 38.2 percent of the total basin areas delineated in the study area.

The debris-flow probabilities in response to the modeled 100-year, 30-minute rainfall event in the Jemez River watershed area (interactive map) range from less than 1 percent to greater than 97 percent and average about 43 percent (median of 41 percent). In this subarea, 302 subbasins have debris-flow probabilities greater than 80 percent. Some of these subbasins with a high probability of debris flows are concentrated in an area of upland tributaries to the Rio Cebolla and Jemez River watersheds, and many are associated with San Antonio Creek in the caldera (fig. $1 B$ ), although many others are scattered throughout the Jemez River watershed area. There are no subbasins in this watershed area with estimated debris-flow volumes greater than $100,000 \mathrm{~m}^{3}$. The estimated debris-flow volumes in this area range from slightly more than $30 \mathrm{~m}^{3}$ to nearly $100,000 \mathrm{~m}^{3}$ and average around 4,000 $\mathrm{m}^{3}$ (median of 1,200 $\mathrm{m}^{3}$ ). Debris flows in the tributaries to the Rio Cebolla, Jemez River, and San Antonio Creek could negatively affect water quality in the Jemez River, recreational uses associated with the Jemez River and the riparian areas, health of the riparian areas, and communities downstream including Jemez Springs, Jemez Pueblo, San Ysidro, and Zia Pueblo. 


\section{Integrated Relative Debris-Flow Hazard Index Rankings}

The 4,998 subbasins in the study area were ranked from highest (1) to lowest $(4,998)$ integrated relative debris-flow hazard index (integrated debris-flow hazard on interactive map). This integrated hazard index provided a relative ranking of subbasins ranging from those with the highest probabilities of producing large-volume debris flows in areas most likely to have fires to those with the lowest probabilities of producing small-volume debris flows in areas least likely to have fires. Because this is a relative ranking, there are only subtle differences in the rankings of relative debris-flow hazard between the six different storm events modeled.

The subbasins with integrated relative debris-flow hazard index values in the top 2 percent of the integrated hazardindex ranking (approximately 100) typically are large, upland tributaries to canyons and channels primarily in the Upper Rio Grande and Rio Grande--Santa Fe watershed areas. Many of the high-hazard areas in the Upper Rio Grande and Rio Grande-Santa Fe watershed areas already had significant mass-wasting episodes following the Las Conchas fire. Other subbasins with integrated hazard-index values in the top 2 percent are scattered throughout the Jemez River watershed area, including some subbasins in the interior of the caldera. Only a few subbasins in the top integrated hazard index group are in the Rio Chama watershed area.

The wildfire and debris-flow probability model simulation results for the 4,998 subbasins in the study area are shown in figure 6 using a scatterplot of the 100-year recurrence interval, 30-minute duration rainfall event (referred to as the 100-year design storm) debris-flow volumes with debris-flow likelihood indexes (postwildfire debris-flow probability multiplied by annual burn probability) for all subbasins. The 4,998 subbasins are divided into three categories based on the rankings of their integrated relative debris-flow hazard indexes - top 2 percent, top 10 percent, and lowest 90 percent of subbasins (remaining subbasins in figure 6). Reference lines for common percentile breakdowns also are shown on the scatterplot of conditional volumes with debris-flow likelihood index for all modeled subbasins. All subbasins with integrated hazardindex values in the top 2 percent have basin areas greater than $1 \mathrm{~km}^{2}$. Thus, when looking at the combined hazards of debris-flow probability, estimated debris-flow volume, and burn probability, the many smaller subbasins in the study area,
87.7 percent of which are less than $1 \mathrm{~km}^{2}$, are not likely to create the largest hazards. Estimated debris-flow volume is partly a function of basin area, so smaller subbasins generally will have smaller estimated debris-flow volumes. However, although only subbasins with areas greater than $1 \mathrm{~km}^{2}$ were in the top 2 percent of integrated hazard-index rankings, the highest hazard group includes subbasins with estimated volumes ranging from as low as nearly $20,000 \mathrm{~m}^{3}$ to greater than $180,000 \mathrm{~m}^{3}$, the highest volume estimated in the entire study area (fig. 6).

Within the Upper Rio Grande watershed area, only Santa Clara Canyon has eight subbasins in the top 2 percent of integrated hazard-index rankings and nearby Guaje Canyon has five subbasins in the top 2 percent. Within the Rio Grande-Santa Fe watershed area, nearly all the large subbasin tributaries on the western slopes of Peralta Canyon (fig. 1B) are in the top 2 percent of integrated hazard rankings. Most of the large tributaries to Cochiti and Bland Canyons, east of Peralta Canyon, also have high integrated hazard rankings. These areas are all in the Las Conchas burn perimeter (fig. 4). Subbasins in the Jemez River watershed area with integrated hazard rankings in the top 5 percent or even in the top 2 percent are too numerous to mention. Some are in areas previously burned by the Las Conchas or Thompson Ridge Fires, but others in the western side of the watershed area are in areas that have not recently burned.

\section{Supporting Evidence}

Following the Las Conchas Fire, floods and debris flows have been particularly well documented in canyons where there are integrated hazard-index values indicating high risk, such as Santa Clara, Cochiti, and upper Frijoles Canyon. Flooding and sediment-related issues in Santa Clara Canyon led to two Federal Disaster Declarations in the span of 1 month (Indian Country Today Media Network staff, 2013). After the Thompson Ridge Fire in the Valles Caldera, debris flows were documented (Pelletier and Orem, 2014) in subbasins in the study area that were estimated to have 80 percent or higher probability of debris-flow occurrence. Examples of typical debris-flow deposits associated with tributary channels in upper Frijoles and Santa Clara Canyons and how influx of debris from upland tributaries can affect flood-debris deposition in downstream main channels are shown in figure 7. 


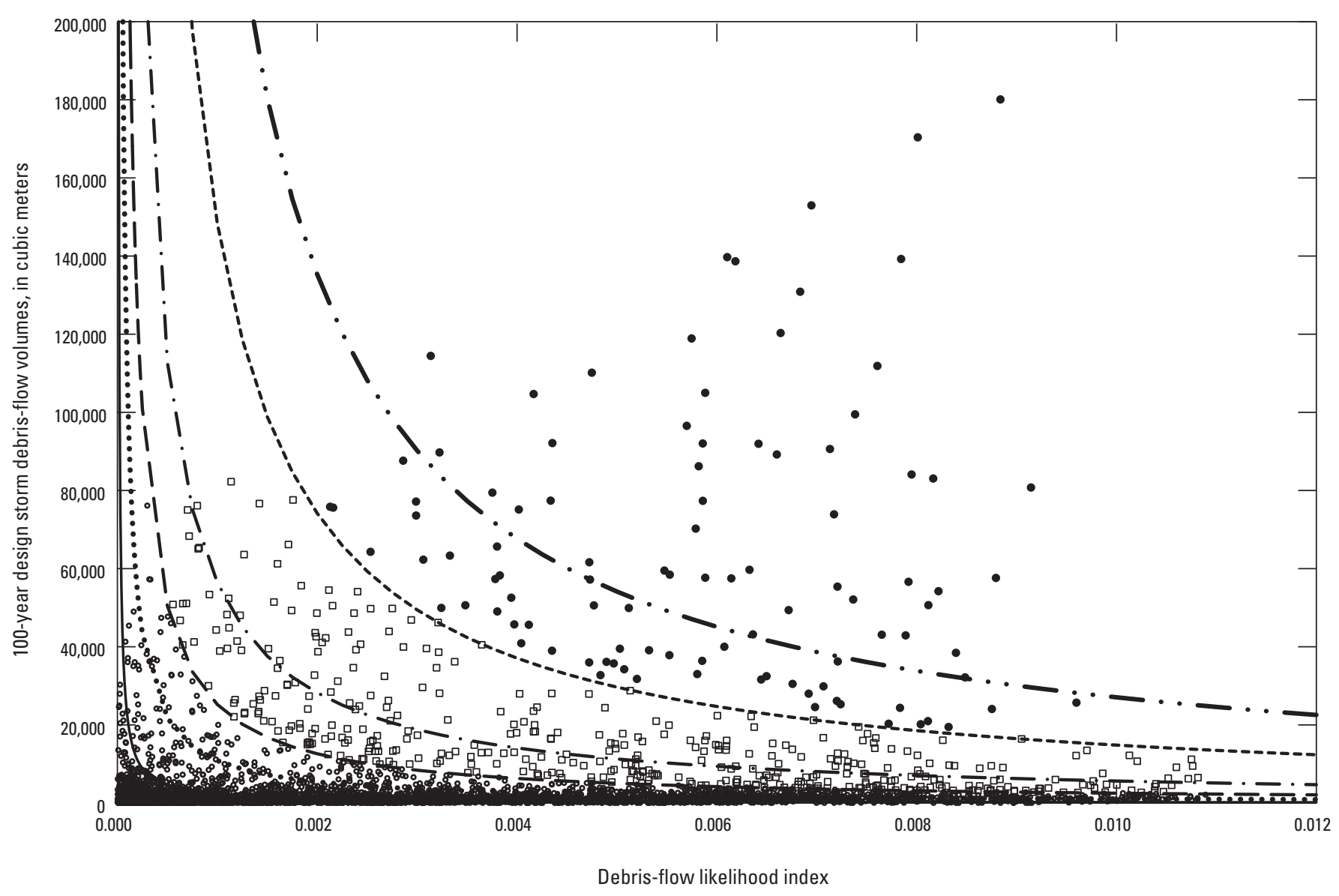

EXPLANATION

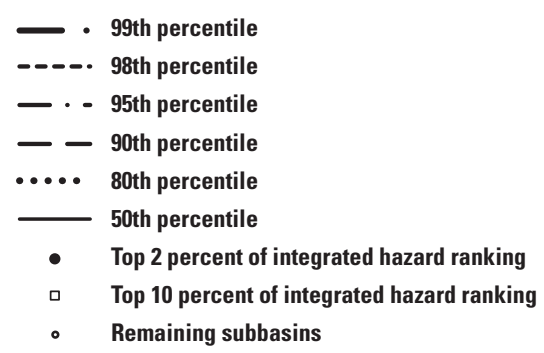

Figure 6. Conditional debris-flow volume with debris-flow likelihood index for all modeled subbasins, Jemez Mountains, north-central New Mexico. Conditional debris-flow volumes are for the 100 -year storm with 30-minute rainfall duration. 

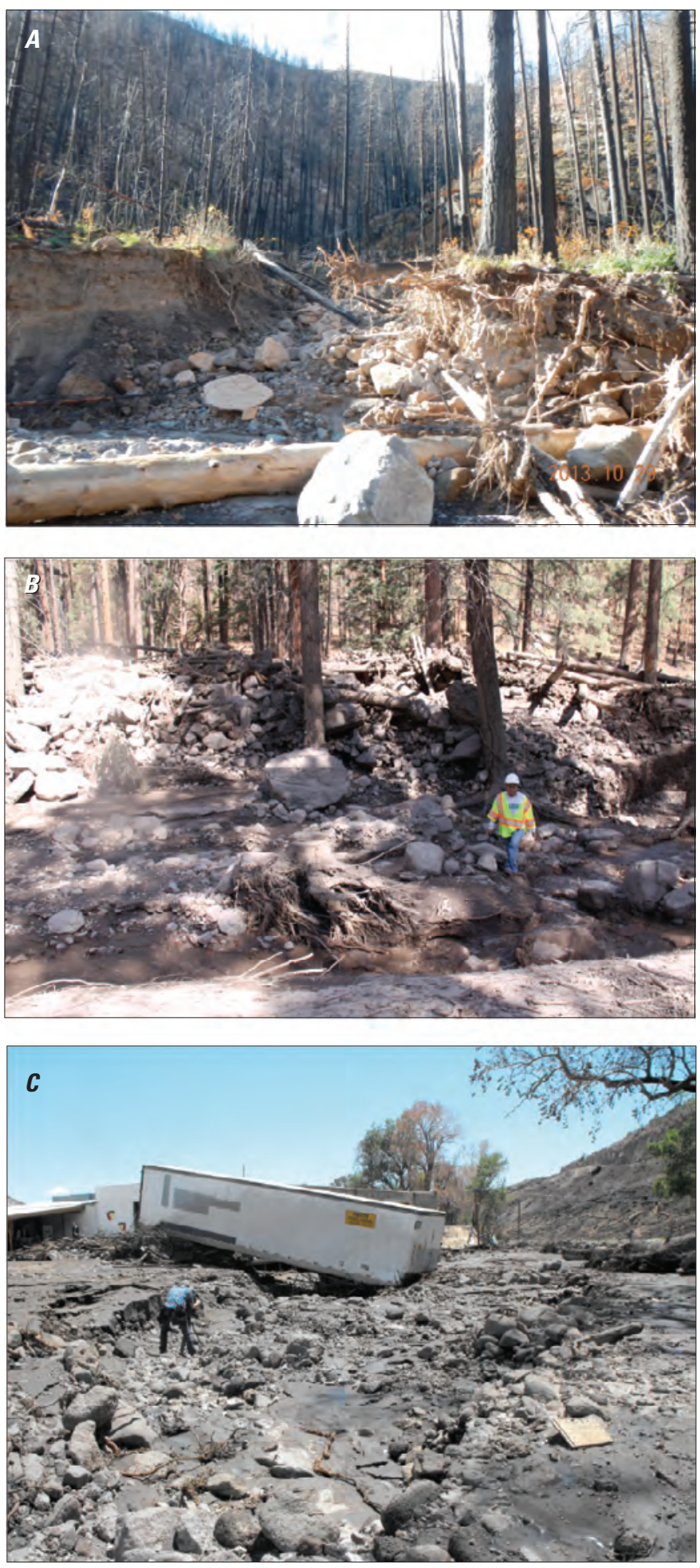

Figure 7. Debris-flow deposits $(A)$ associated with a tributary of Rito de los Frijoles, near the Upper Crossing in Bandelier National Monument with an Integrated Relative Debris-Flow Hazard Index Ranking in the top 20 percentile; $(B)$ in Santa Clara Canyon; and (C) combined effects of upstream influx of debris in the main channel of Cochiti Canyon, Jemez Mountains, north-central New Mexico. Photographs by (A) A.C. Tillery, U.S. Geological Survey, October 30, 2013; (B) Jeb Brown, U.S. Geological Survey, July 16, 2012; and (C) Kerry Jones, National Weather Service, August 22, 2011.

\section{Limitations of Debris-Flow Hazard Assessment}

A detailed discussion on the limitations of debris-flow hazard assessments using the methodology applied in this report is available in Tillery and others (2014). This section provides information from the discussion of limitations taken from that report.

The use of models for forecasting uncertain events necessarily comes with limitations and potential errors, particularly when multiple models are combined. With respect to both wildfire and debris-flow modeling, a limited empirical basis for model calibration purposes may not be capturing the full range of possible outcomes, highlighting a need for updating models as new observations are made. Limitations and uncertainties specific to fire-modeling tools include an incomplete understanding of how uncertainty and errors propagate through models and knowledge gaps relating to crown-fire potential and propagation, fire-atmosphere dynamics, and fire-fuel interactions (Scott and others, 2012). Further, the spatial aggregation of basin average burn probabilities for continuous parameterization purposes likely is masking finer scale variation because of topography and local fuel conditions. These factors may partly explain why the subbasin burn-probability index is not a strong factor influencing the integrated relative debris-flow hazard index rankings.

The probability of debris flow increases with increasing recurrence interval (larger, less frequent) design storms. Larger, less frequent storms (for example, a 50-year recurrence interval rainfall event) are likely to produce larger debris flows, whereas smaller, more frequent storms (for example, a 1-year recurrence interval rainfall event) also could trigger debris flows, but the resulting debris flows likely would be smaller. Higher probabilities of debris flows than those delineated in this study may exist within any part of the drainage basins. Because most rainstorms will not be large enough to affect the entire burn area, debris flows will not be produced from all drainage basins during a given storm.

The interactive maps categorize only those areas from which debris will be moved and do not categorize those areas that can be affected by debris flows as the material moves downstream of the basin outlets (Cannon and others, 2010).

The variables included in the debris-flow models and used in this assessment are considered to directly affect debris-flow generation in the intermountain Western United States. Conditions other than those used in the models (for example, the amount of sediment stored in a canyon) also could affect debris-flow production. Data necessary to evaluate such effects, however, are not readily available. 
The continuous parameterization technique, although efficient for analytical purposes, may be masking localized variation in conditions affecting either wildfire potential or debris-flow potential. Fine-scale variability in surface characteristics that are not captured by the independent variables used in the model (such as local sediment supply or differences in infiltration rates) may substantially affect debris-flow generation and propagation.

The debris-flow model is considered valid for conditions that typically persist in a burned watershed for 1 to several years after a fire. The model does not account for variations in the timing of landscape recovery after a fire. The rate of recovery of individual landscapes will vary particularly with respect to postwildfire rainfall amount, timing, and intensity.

The debris-flow analysis is based on simulated postwildfire conditions and does not account for potential mitigating effects of prewildfire treatments, such as forest thinning or prescribed burning. The analysis highlights, especially by the stream segment analysis, those parts of a basin with an increased debris-flow probability based on physical characteristics. The information provided by this study should be considered together with local expertise and information to guide mitigation and restoration planning.

This study was designed to help select ideal locations for watershed restoration that could have the best return on investment. The study provides information on which watersheds might constitute the most serious, potential, debris-flow hazards in the event of a large-scale wildfire and subsequent rainfall in the Jemez Mountains areas. The maps and geospatial data provided with this report may be used to prioritize areas where forest thinning or other protective measures may be needed prior to wildfires in these drainage basins, their outlets, or areas downstream of these drainage basins to help reduce potential burn severities. This assessment evaluates only postwildfire debris flows and does not consider hazards associated with flash floods; such hazards may remain for many years after a fire.

\section{Future Considerations for Prewildfire Assessments of Postwildfire Hazards}

This study has extended the applications of several models beyond the scope of their original designs. The debris-flow models described in this report were designed for postwildfire assessments; for this study, they were applied before any fire occurred. The FlamMap model was designed to simulate fire behavior; for this study, it was used to estimate burn severity. The FSim model was developed to present spatially specific burn probabilities; for this study, the FSim output was averaged over subbasin areas and combined with outputs from the debris-flow and FlamMap models to compute an integrated relative debrisflow hazard index for each basin. These extensions of the original model applications are not ideal but were used because of the need for prioritization of prewildfire hazards and associated mitigation efforts. Individually, these models are difficult to verify and the errors associated with combining them in the manner used here will be difficult to verify as well. Although this methodology represents a step forward in how prewildfire assessments of potential hazards are evaluated, the methodology is still in the early stages of development and will continue to evolve as similar studies are completed.

\section{Implications for Burn-Severity Mitigation Measures in the Jemez Mountains}

This study is being done to help land managers prioritize wildfire-mitigation efforts such as forest thinning, therefore, an effort was made to quantify how a reduction in basin burn severity, that may be the result of forest thinning, would affect basin debris-flow probabilities in the Jemez Mountains. Multiple burn-severity scenarios were developed using the 4,998 subbasins available from this study. The range of spatial variables (for the Jemez Mountains dataset) that are considered in the debris-flow basin probability equations is shown in table 3. To develop the multiple burn-severity scenarios, the debris-flow probability equation was solved for all subbasins with all factors held constant at original values except for the percentage of drainage basin area burned at moderate and high severity, which was systematically decreased by 10-percent increments from 100 to 50 percent for each computation. The results of this modeling exercise suggest that a 10-percent decrease in percentage of drainage basin area burned at moderate and high severity could reduce debris-flow probability by as much as 15 percent (table 4 ).

Table 3. Debris-flow probability factors calculated for the 4,998 subbasins dataset for Jemez Mountains, north-central New Mexico.

\begin{tabular}{lrrr}
\hline \multicolumn{1}{c}{$\begin{array}{c}\text { Debris-flow } \\
\text { probability factor }\end{array}$} & Maximum & Minimum & Mean \\
\hline $\begin{array}{l}\text { Drainage basin ruggedness } \\
\text { Slope greater than 30 percent }\end{array}$ & 3.2 & 0.01 & 0.5 \\
$\begin{array}{l}\text { Percentage of drainage basin area } \\
\quad \text { burned at moderate and high severity }\end{array}$ & 100.0 & 0.00 & 35.0 \\
$\begin{array}{l}\text { Percent basin clay content of the soil } \\
\text { Liquid limit of the soil }\end{array}$ & 33.9 & 8.0 & 58.1 \\
$\begin{array}{l}\text { Average 100-year, 30-minute storm } \\
\quad \text { intensity, in millimeters }\end{array}$ & 41.9 & 22.9 & 19.8 \\
& 69.2 & 48.9 & 55.5 \\
\hline
\end{tabular}


This modeling exercise is intended to provide land-use managers with information on how debris-flow probabilities might be decreased by mitigation efforts aimed at reducing burn severity in the Jemez Mountains. This exercise does not include scenarios where debris-flow factors extend beyond the range of factors for the Jemez Mountains (table 3). The percentage of reduction in debris-flow probability with 10-percent reduction of high and moderate burn severity starts at 15.2 percent and decreases slightly as the reduction in burn severity increases. The attenuation in the decrease in debris-flow probabilities as burn severity is reduced is likely because some subbasins originally had low percentages of drainage basin area burned at moderate- and high-severity values. A decrease in percentage of drainage basin area burned at moderate and high severity from 100 to 90 percent has a much greater effect on the debris-flow probability equation than a decrease from 0.01 to 0.009 percent. Each time the burn-severity values are reduced by another 10 percent, the total number of subbasins with negligible burn-severity values increases. This effect can be visualized by plotting the difference in median and mean basin debris-flow probabilities with percentage of reduction in burn severity (fig. 8). In each case, the median value is less than the mean value by at least 5 percent and as much as 8.4 percent, indicating that the outlier values are on the upper end of the range of values.

Table 4. Debris-flow probability scenarios, Jemez Mountains, north-central New Mexico.

[Debris flow probability decreases with decreasing basin burn severity (100 percent equals original condition)]

\begin{tabular}{ccccccccc}
\hline $\begin{array}{c}\text { Original basin } \\
\text { high and moderate } \\
\text { burn severity } \\
\text { (percent) }\end{array}$ & $\begin{array}{c}\text { Basin debris- } \\
\text { flow probability } \\
\text { (percent) }\end{array}$ & $\begin{array}{c}\text { Percent change } \\
\text { from original } \\
\text { condition }\end{array}$ & $\begin{array}{c}\text { Isolated } \\
\text { change } \\
\text { (percent) }\end{array}$ & & $\begin{array}{c}\text { Debris-flow } \\
\text { probabilities } \\
\text { (percent) }\end{array}$ & $\begin{array}{c}\text { Percent change } \\
\text { from original } \\
\text { condition }\end{array}$ & $\begin{array}{c}\text { Isolated } \\
\text { change } \\
\text { (percent) }\end{array}$ \\
\hline 100 & 37.2 & 0.0 & 0.0 & & 30.6 & 0.0 & 0.0 \\
90 & 31.5 & -15.2 & -15.2 & & 23.7 & -22.7 & -22.7 \\
80 & 25.9 & -30.2 & -15.0 & & 17.6 & -42.7 & -20.0 \\
70 & 20.6 & -44.5 & -14.3 & & 12.9 & -58.0 & -15.3 \\
60 & 15.9 & -57.3 & -12.8 & & 9.4 & -69.3 & -11.3 \\
50 & 11.8 & -68.3 & -11.0 & & 6.7 & -78.0 & -8.7 \\
\hline
\end{tabular}

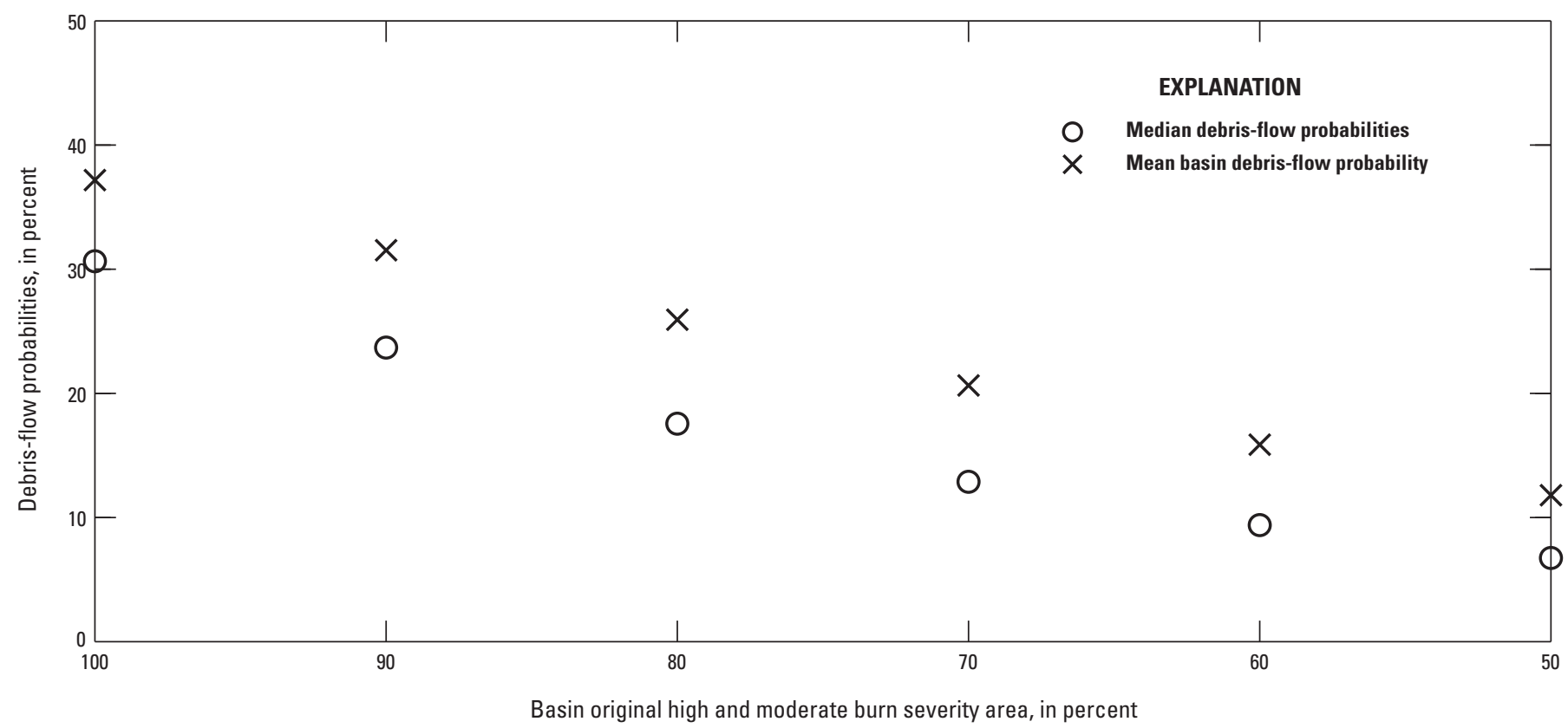

Figure 8. Basin debris-flow probabilities as a percentage of reduction in high and moderate burn severity, Jemez Mountains, north-central New Mexico. 


\section{Summary}

Debris flows are high-density slurries of water, rock fragments, soil, and mud that can have enormous destructive power, particularly when they are fast moving. Wildfire can substantially increase the probability of debris flows in landscapes that otherwise have been stable throughout recent history. A prewildfire evaluation to determine potential for postwildfire debris flows in the Jemez Mountains in north-central New Mexico was started in 2014 by the U.S. Geological Survey in cooperation with the Buckman Direct Diversion Board, the U.S. Forest Service (USFS), the Albuquerque/Bernalillo County Water Utility Authority, the U.S. Army Corps of Engineers, and Los Alamos County as a part of the Rio Grande Water Fund. The USFS provided support for this effort, primarily through fire-simulation modeling.

The study was done to provide information on which watersheds might constitute the most serious, potential, debris-flow hazards in the event of a large-scale wildfire and subsequent rainfall in the Jemez Mountain areas. The USFS fire-behavior model FlamMap was used to estimate the burn severity likely to occur in unburned areas of the Jemez Mountains. The USFS large-fire simulation system (FSim) was used to estimate the probability of fire spreading across all areas of the Jemez Mountains and beyond. The U.S. Geological Survey post-wildfire debris flow model was used to estimate the probabilities of debris flows and of volumes of material that could be removed from subbasins based on topography, soil characteristics, and simulated burn intensities.

A total of 4,998 subbasins ranging in size from 0.01 to 6.57 square kilometers $\left(\mathrm{km}^{2}\right)$ and encompassing an area of $2,570 \mathrm{~km}^{2}$ were modeled in this study. The results of this study indicate that a wide range of postwildfire hazards are present in the Jemez Mountains areas. Those areas with the highest simulated hazards generally are typically large, upland tributaries to canyons and channels primarily in the Upper Rio Grande and Rio Grande-Santa Fe watershed areas.

Across the entire study area, the probabilities of debris flows in response to the 100-year-recurrence interval, 30 -minute duration rainfall event range from less than 1 percent to greater than 98 percent, average 37 percent, and have a median of 31 percent, with 671 subbasins (13.4 percent of all subbasins) having debris-flow probabilities greater than 80 percent. When comparing debris-flow probability results between the 25-year and 100-year recurrence-interval rainfall events, subbasin debris-flow probabilities greater than 90 percent increase almost 2.5 times across the study area. The number of subbasins with debris-flow probabilities greater than 80 percent is 144 percent higher (13.4 percent of all subbasins) when comparing the 100 -year recurrence interval rainfall event to the 25-year event. Estimated debrisflow volumes in response to the 100-year recurrence interval, 30 -minute duration rainfall range from slightly greater than 30 cubic meters $\left(\mathrm{m}^{3}\right)$ to greater than $180,000 \mathrm{~m}^{3}$, average greater than $4,500 \mathrm{~m}^{3}$ and have a median of $1,200 \mathrm{~m}^{3}$.
The rankings of integrated relative debris-flow hazard indexes for each subbasin were generated by multiplying the individual subbasin values for debris-flow volume, debrisflow probability, and average burn probability. The analysis shows that most of the subbasins with the highest rankings for integrated relative debris-flow-hazard indexes typically are large, upland tributaries to canyons and channels primarily in the Upper Rio Grande and Rio Grande-Santa Fe watershed areas. There are no subbasins in this group with basin areas less than $1 \mathrm{~km}^{2}$. Many of these areas already had significant mass-wasting episodes following the Las Conchas Fire. Other subbasins with top-2-percent integrated hazard index values are scattered throughout the Jemez River watershed area, including some subbasins in the interior of the caldera. Only a few subbasins in the top integrated hazard index group are in the Rio Chama watershed area.

The maps provided with this report may be used to prioritize areas where forest thinning or other protective measures may be needed prior to wildfires in these drainage basins, at their outlets, or in areas downstream of these drainage basins to help reduce potential burn severities. Preliminary analysis indicates that decreases of 10 percent in the percentage of drainage basin area burned at moderate and high severity can reduce debris-flow probabilities by as much as 15 percent in the Jemez Mountains. This assessment evaluates only postwildfire debris flows and does not consider hazards associated with flash floods; such hazards may remain for many years after a fire.

\section{Acknowledgments}

The authors acknowledge Dennis Staley of the USGS Landslide Hazards Program and Kris Verdin of the USGS Colorado Science Center for providing excellent and helpful peer reviews.

\section{References Cited}

Ager, A.A., Vaillant, N.M., Finney, M.A., and Preisler, H.K., 2012, Analyzing wildfire exposure and sourcesink relationships on a fire prone forest landscape: Forest Ecology and Management, v. 267, p. 271-283.

Alexander, M.E., and Cruz, M.G., 2012, Interdependencies between flame length and fireline intensity in predicting crown fire initiation and crown scorch height: International Journal of Wildland Fire, v. 21, p. 95-113.

Allen, C.D., 1989, Changes in the landscape of the Jemez Mountains, New Mexico: Berkeley, University of California, Ph.D. dissertation, $346 \mathrm{p}$. 
Allen, C.D., 2001, Fire and vegetation history of the Jemez Mountains, in Johnson, P.S., ed., Water, watersheds, and land use in New Mexico-Impacts of population growth on natural resources, Santa Fe region 2001: Socorro, New Mexico Bureau of Mines and Mineral Resources, p. 29-33.

Allen, C.D., Savage, M., Falk, D.A., Suckling, K.F., Swetnam, T.W., Schulke, T., Stacey, P.B., Morgan, P., Hoffman, M., and Klingel, J.T., 2002, Ecological restoration of southwestern ponderosa pine ecosystems - A broad perspective: Ecological Applications, v. 12, no. 5, p. $1,418-1,433$.

Bahro, B., Barber, K.H., Sherlock, J.W., and Yasuda, D.A., 2007, Stewardship and fireshed assessment-A process for designing a landscape fuel treatment strategy restoring fire-adapted ecosystems-Proceedings of the 2005 National Silviculture Workshop, Albany, California, U.S. Department of Agriculture, U.S. Forest Service, Pacific Southwest Research Station, General Technical Report PSW-GTR-203, p. 41-54.

Balling, R.C., Jr., Meyer, G.A., and Wells, S.G., 1992, Climate change in Yellowstone National Park-Is the droughtrelated risk of wildfires increasing?: Climatic Change, v. 22, p. 35-45.

Bandelier National Monument, 2012, The Las Conchas Fire and Bandelier: Bulletin provided by the Resource Management Division, Bandelier National Monument, 2 p., accessed September 17, 2015, at http://www.nps.gov/band/ learn/nature/upload/BAER-las-conchas.pdf.

Bonnin, G.M., Martin, D., Lin, B., Parzybok, T., Yekta, M., and Riley, D., 2004, Precipitation-frequency atlas of the United States-Volume 1, Version 5.0, Semiarid Southwest (Arizona, southeast California, Nevada, New Mexico, and Utah): Silver Spring, Maryland, National Oceanic and Atmospheric Administration Atlas 14, 271 p.

Burton, B.W., 1982, Geologic evolution of the Jemez Mountains and their potential for future volcanic activity: Los Alamos, New Mexico, Los Alamos National Laboratory Report LA-8795-GEOL, $31 \mathrm{p}$.

Cannon, S.H., Bigio, E.R., and Mine, E., 2001, A process for fire-related debris flow initiation, Cerro Grande fire, New Mexico: Hydrological Processes, v. 15, no. 15, p. 3,011-3,023.

Cannon, S.H., and Gartner, J.E., 2005, Wildfire-related debris flow from a hazards perspective, chap. 15 of Jakob, M., and Hungr, O., eds., Debris-flow hazards and related phenomena: Berlin, Praxis, Springer-Verlag, p. 363-385.
Cannon, S.H., Gartner, J.E., Rupert, M.G., Michael, J.A., Rea, A.H., and Parrett, C., 2010, Predicting the probability and volume of postwildfire debris flows in the intermountain Western United States: Geological Society of America Bulletin, v. 122, p. 127-144.

Cannon, S.H., Kirkham, R.H., and Parise, M., 2001, Wildfirerelated debris-flow initiation processes, Storm King Mountain, Colorado: Geomorphology, v. 39, nos. 3-4, p. $171-188$.

Coe, J.A., Kinner, D.A., and Godt, J.W., 2008, Initiation conditions for debris flows generated by runoff at Chalk Cliffs, central Colorado: Geomorphology, v. 96, nos. 3-4, p. 270-297.

Covington, W.W., and Moore, M.M., 1994, Southwestern ponderosa forest structure: Journal of Forestry, v. 92, no. 1, p. 39-47.

DeGraff, J.V., Wagner, D., Gallegos, A.J., DeRose, M., Shannon, C., and Ellsworth, T., 2011, The remarkable occurrence of large rainfall-induced debris flows at two different locations on July 12, 2008, Sierra Nevada, California: Landslides, v. 8, no. 2, p. 343-353.

de Smith, M.J., Goodchild, M.F., and Longley, P.A., 2015, Geospatial analysis-A comprehensive guide to principles, techniques and software tools, 5th edition: Winchelsea, United Kingdom, The Winchelsea Press, p. 748.

Environmental Systems Resource Institute, 2011, ArcMap 10.1: Redlands, California, Environmental Systems Resource Institute software.

Finney, M.A., 2006, An overview of FlamMap fire modeling capabilities, in Proceedings of the Fuels ManagementHow to Measure Success Conference, Portland, Oregon, January 2006: Fort Collins, Colorado, U.S. Forest Service, Rocky Mountain Research Station, p. 213-220.

Finney, M.A., McHugh, C.W., Grenfell, I.C., Riley, K.L., and Short, K.S., 2011, A simulation of probabilistic wildfire risk components for the continental United States: Stochastic Environmental Research and Risk Assessment, v. 25, no. 7, p. $973-1,000$.

Fleck, J., 2011, Fire debris shuts Cochiti to boating: Albuquerque Journal, August 24, 2011, accessed September 9, 2015, at http://www.abqjournal.com/51925/news/firedebris-shuts-cochiti-to-boating.html.

Gallaher, B.M., and Koch, R.J., 2004, Cerro Grande fire impacts to water quality and stream flow near Los Alamos National Laboratory - Results of four years of monitoring: Los Alamos, New Mexico, Los Alamos National Laboratory Report LA-14177, 195 p., accessed September 2015 at https://www.env.nm.gov/swqb/Wildfire/4.CerroGrandePostfire_Report.pdf. 
Gartner, J.E., Cannon, S.H., Bigio, E.R., Davis, N.K., Parrett, C., Pierce, K.L., Rupert, M.G., Thurston, B.L., Trebish, M.J., Garcia, S.P., and Rea, A.H., 2005, Compilation of data relating to the erosive response of 608 recently burned basins in the Western United States: U.S. Geological Survey Open-File Report 2005-1218.

Gesch, D., Oimoen, M., Greenlee, S., Nelson, C., Steuck, M., and Tyler, D., 2002, The national elevation dataset: Photogrammetric Engineering and Remote Sensing, v. 68, no. 1, p. 5-11.

Haas, J.R., Calkin, D.E., and Thompson, M.P., 2013, A national approach for integrating wildfire simulation modeling into wildland urban interface risk assessments within the United States: Landscape and Urban Planning, v. 119, p. 44-53.

Helsel, D.R., and Hirsch, R.M., 2002, Statistical methods in water resources: U.S. Geological Survey Techniques of Water-Resources Investigations, book 4, chap. A3, 510 p.

Indian Country Today Media Network, 2013, Second FEMA disaster declaration for flooded Santa Clara Pueblo in a month: Indian Country Today Media Network.com, October 25, 2014, accessed September 3, 2015, at http:// indiancountrytodaymedianetwork.com/2013/10/25/secondfema-disaster-declaration-flooded-santa-clara-pueblomonth-151934.

Johansen, M.P., Hakonson, T.E., and Breshears, D.D., 2001, Post-fire runoff and erosion from rainfall simulationContrasting forest with shrublands and grasslands: Hydrological Processes, v. 15, p. 2,953-2,965.

Kean, J.W., Staley, D.M., and Cannon, S.H., 2011, In situ measurements of post-fire debris flows in southern California - Comparisons of the timing and magnitude of 24 debris-flow events with rainfall and soil moisture conditions: Journal of Geophysical Research, v. 116, 21 p.

Keeley, J.E., 2009, Fire intensity, fire severity and burn severity-A brief review and suggested usage: International Journal of Wildland Fire, v. 18, no. 1, p. 116-126.

Keeley, J.E., Brenna, T., and Pfaff, A.H., 2008, Fire severity and ecosystem responses following crown fires in California shrublands: Ecological Applications, v. 18, no. 6, p. 1,530-1,546.

Melton, M.A., 1965, The geomorphic and paleoclimatic significance of alluvial deposits in southern Arizona: Journal of Geology, v. 73, p. 1-38.

National Wildfire Coordinating Group, 2015, National Incident Management System-Wildfire fire qualification system guide PMS 310-1: National Wildfire Coordinating Group Operations Training Committee, accessed October 2015, at http://www.nwcg.gov/publications/310-1.
New Mexico Governor's Drought Task Force, 2015, Short term drought lessening its grip on New Mexico-Summary of current status: New Mexico Governor's Drought Task Force, Monitoring Working Group, August 2015, accessed August 12, 2015, at http://www.nmdrought.state. nm.us/MonitoringWorkGroup/2015/08/(2)\%20DMWG_ DroughtReport-082515.pdf.

New Mexico Legislature, 2014, Legislative Health and Human Services Committee handouts, item 1, October 20, 2014 : New Mexico Legislature Web site, accessed September 3, 2015, at http://www.nmlegis.gov/lcs/committee_handout_ list.aspx?CommitteeCode=LHHS\&Date=10/20/2014.

Pelletier, J.D., and Orem, C.A., 2014, How do sediment yields from post-wildfire debris-laden flows depend on terrain slope, soil burn severity class, and drainage basin area?Insights from airborne-LiDAR change detection: Earth Surface Processes and Landforms, v. 39, no. 13, p. $1,822-1,832$.

Pierce, J.L., Meyer, G.A., and Timothy Jull, A.J., 2004, Fireinduced erosion and millennial-scale climate change in northern ponderosa pine forests: Nature, v. 432, p. 87-90.

Pyne, S.J., 2015, Between two fires-A fire history of contemporary America: Tucson, University of Arizona Press, $550 \mathrm{p}$.

Pyne, S.J., Andrews, P.L., and Laven, R.D., 1996, Introduction to wildland fire ( $2 \mathrm{~d}$ ed.): New York, John Wiley and Sons, 808 p.

Rothermel, R.C., 1972, A mathematical model for predicting fire spread in wildland fuels: Ogden, Utah, U.S. Department of Agriculture, U.S. Forest Service, Intermountain Forest and Range Experiment Station, Research Paper INT-115, $40 \mathrm{p}$.

Ryan, K.C., 2002, Dynamic interactions between forest structure and fire behavior in boreal ecosystems: Silva Fennica, v. 36, p. 13-39.

Ryan, K.C., and Opperman, T.S., 2013, LANDFIRE-A national vegetation/fuels data base for use in fuels treatment, restoration, and suppression planning: Forest Ecology and Management, v. 294, p. 208-216, accessed September 2014, at http://landfire.gov.

Schwartz, G.E., and Alexander, R.B., 1995, Soils data for the conterminous United States derived from the NRCS State Soil Geographic (STATSGO) data base (ed. 1.1): U.S. Geological Survey Open-File Report 95-449.

Scott, J., Helmbrecht, D., Thompson, M.P., Calkin, D.E., and Marcille, K., 2012, Probabilistic assessment of wildfire hazard and municipal watershed exposure: Natural Hazards, v. 64 , no. 1 , p. $707-728$. 
Scott, J.H., and Burgan, R.E., 2005, Standard fire behavior fuel models-A comprehensive set for use with Rothermel's surface fire spread model: Fort Collins, Colorado, U.S. Department of Agriculture, U.S. Forest Service, Rocky Mountain Research Station, General Technical Report RMRS-GTR-153, 72 p.

Scott, J.H., and Reinhardt, E.D., 2001, Assessing crown fire potential by linking models of surface and crown fire behavior: Fort Collins, Colorado, U.S. Forest Service, Rocky Mountain Research Station, Research Paper RMRS-RP-29, 59 p.

Scott, J.H., Thompson, M.P., and Calkin, D.E., 2013, A wildfire risk assessment framework for land and resource management: Fort Collins, Colorado, U.S. Department of Agriculture, U.S. Forest Service, Rocky Mountain Research Station, General Technical Report RMRS-GTR-315, 83 p.

Stratton, R.D., 2004, Assessing the effectiveness of landscape fuel treatments on fire growth and behavior: Journal of Forestry, October-November, v. 102, no. 7, p. 32-40.

Stratton, R.D., 2009, Guidebook on LANDFIRE fuels data acquisition, critique, modification, maintenance, and model calibration: Fort Collins, Colorado, U.S. Department of Agriculture, U.S. Forest Service, Rocky Mountain Research Station, General Technical Report RMRS-GTR-220, 54 p.

Swetnam, T., and Baisan, C., 1996, Historical fire regime patterns in the southwestern United States since AD 1700, in Allen, C.D., ed., Fire effects in southwestern forest: Proceedings of the Second La Mesa Fire Symposium, Los Alamos, New Mexico, March 29-31, 1994, U.S. Department of Agriculture, U.S. Forest Service, General Technical Report RM-GTR-286, p. 11-32.

Swetnam, T.W., and Bentancourt, J.L., 1990, Fire-Southern Oscillation relations in the southwestern United States: Science, v. 249, p. 1,017-1,020.

The Nature Conservancy, 2014, Rio Grande water fundComprehensive plan for wildfire and water source protection: The Nature Conservancy, 43 p., accessed September 4, 2013, at http://www.nmconservation.org/ RGWF/RGWF_CompPlan.pdf.

Thompson, M.P., Calkin, D.E., Finney, M.A., Ager, A.A., and Gilbertson-Day, J.W., 2011, Integrated national-scale assessment of wildfire risk to human and ecological values: Stochastic Environmental Research and Risk Assessment, v. 25 , p. $761-780$.
Thompson, M.P., Scott, J., Helmbrecht, D., and Calkin, D.E., 2013, Integrated wildfire risk assessmentFramework development and application on the Lewis and Clark National Forest in Montana, USA: Integrated Environmental Assessment and Management, v. 9, no. 2, p. 329-342.

Tillery, A.C., Haas, J.R., Miller, L.W., Scott, J.H., and Thompson, M.P., 2014, Potential postwildfire debris-flow hazards-A prewildfire evaluation for the Sandia and Manzano Mountains and surrounding areas, Central New Mexico: U.S. Geological Survey Scientific Investigations Report 2014-5161, 23 p. with appendix, http://dx.doi. org/10.3133/sir20145161.

Touchan, R., Allen, C.D., and Swetnam, T.W., 1996, Fire history and climatic patterns in ponderosa pine and mixed-conifer forests of the Jemez Mountains, northern New Mexico: Proceedings of the Second La Mesa Fire Symposium, Los Alamos, New Mexico, March 29-31 1994, U.S. Department of Agriculture, U.S. Forest Service, General Technical Report RM-GTR-286, p. 33-46.

Touchan, R., Woodhouse, C.A., Meko, D.M., and Allen, C., 2011, Millennial precipitation reconstruction for the Jemez Mountains, New Mexico, reveals changing drought signal: International Journal of Climatology, v. 31, p. 896-906.

Turner, M.G., Hargrove, W.W., Gardner, R.H., and Romme, W.H., 1994, Effects of fire on landscape heterogeneity in Yellowstone National Park, Wyoming: Journal of Vegetation Science, v. 5, p. 731-742.

U.S. Army Corps of Engineers, 2012, Environmental assessment and finding of no significant impact for a debriscontainment log boom at Cochiti Lake, Sandoval County, New Mexico: U.S. Army Corps of Engineers, Albuquerque District, accessed September 2015 at http://www.spa.usace. army.mil/Portals/16/docs/environmental/fonsi/Log\%20 Boom\%20FEA_16Aug2012.pdf.

U.S. Census Bureau, 2010, State and county QuickFacts: U.S. Census Bureau Web site, accessed February 2015 at http:// quickfacts.census.gov/qfd/states/35000.html.

U.S. Geological Survey, 2013, LANDFIRE fuels layers: U.S. Geological Survey database, accessed July 2013 at http:// landfire.cr.usgs.gov/viewer/.

U.S. Geological Survey, 2015, GeoMAC-Geospatial MultiAgency Coordination Wildland Fire Support: GeoMAC Wildland Fire Support and U.S. Geological Survey Web site, accessed February 2015 at http://www.geomac.gov/. 
U.S. Geological Survey, 2016, Landslides Hazards Program: U.S. Geological Survey data base, accessed June 2015 at http://landslides.usgs.gov/hazards/postfire_debrisflow/.

Veenhuis, J. E., 2002, Effects of wildfire on the hydrology of Capulin and Rito de los Frijoles Canyons, Bandelier National Monument, New Mexico: U.S. Geological Survey Water-Resources Investigations Report 02-4152, 39 p.

Verdin, K.L., and Greenlee, S., 2003, Continuous basin parameterization using EDNA, in Proceedings of the 2003 Esri User's Conference, San Diego, California, July 7-11, 2003: Redlands, California, Environmental Systems Research Institute, Inc.
Verdin, K.L., and Worstell, B., 2008, A fully distributed implementation of mean annual streamflow regional regression equations: Journal of the American Water Resources Association, v. 44, p. 1,537-1,547, doi: 10.1111/j.1752-1688.2008.00258.x.

Westerling, A.L., Hidalgo, H.G., Cayan, D.R., and Swetnam, T.W., 2006, Warming and earlier spring increase Western U.S. forest wildfire activity: Science, v. 313, 940 p.

Wilson, C.J., Carey, J.W., Beeson, P.C., Gard, M.O., and Lane, L.J., 2001, A GIS-based hillslope erosion and sediment delivery model and its application in the Cerro Grande burn area: Hydrological Processes, v. 15, no. 15, p. 2,995-3,010. 

Publishing support provided by the U.S. Geological Survey

Science Publishing Network, Tacoma Publishing Service Center

For more information concerning the research in this report, contact the Director, New Mexico Water Science Center

U.S. Geological Survey

5338 Montgomery Blvd. NE

Albuquerque, New Mexico 87109

http://nm.water.usgs.gov 
